\title{
Long-Term (1951-2007) Rainfall Trends around Six Indian Cities: Current State, Meteorological, and Urban Dynamics
}

\author{
Shailesh Kumar Kharol, ${ }^{1}$ D. G. Kaskaoutis, ${ }^{2}$ Anu Rani Sharma, ${ }^{3}$ and Ramesh P. Singh ${ }^{4}$ \\ ${ }^{1}$ Department of Physics and Atmospheric Science, Dalhousie University, Halifax, NS, Canada B3H $3 J 5$ \\ ${ }^{2}$ Department of Physics, School of Natural Sciences, Shiv Nadar University, Dadri 203207, India \\ ${ }^{3}$ Department of Natural Resources, TERI University, Vasant Kunj, New Delhi 110 070, India \\ ${ }^{4}$ School of Earth and Environmental Sciences, Schmid College of Science and Technology, Chapman University, \\ Orange, CA 92866, USA
}

Correspondence should be addressed to Ramesh P. Singh; rsingh@chapman.edu

Received 18 July 2013; Revised 18 September 2013; Accepted 3 October 2013

Academic Editor: Samir Pokhrel

Copyright (c) 2013 Shailesh Kumar Kharol et al. This is an open access article distributed under the Creative Commons Attribution License, which permits unrestricted use, distribution, and reproduction in any medium, provided the original work is properly cited.

\begin{abstract}
The present study focuses on analyzing the precipitation trends over six Indian cities during the summer monsoon (JuneSeptember) covering the period 1951-2007 and also attempting to investigate possible urban forcing and dynamics by examining the variation in precipitation in the upwind and downwind directions. The analysis shows negative trends in the total number of rainy days over Hyderabad $(-10.4 \%)$, Kanpur $(-7.1 \%)$, Jaipur $(-10.5 \%)$, and Nagpur $(-4.8 \%)$ and positive trends over Delhi $(7.4 \%)$ and Bangalore (22.9\%). On the other hand, decreases of $-21.3 \%,-5.9 \%,-14.2 \%$, and $-14.6 \%$ in seasonal rainfall are found over Delhi, Hyderabad, Jaipur, and Kanpur, respectively, whereas Bangalore and Nagpur show $65.8 \%$ and $13.5 \%$ increase. The lesser rainfall and rainy days, along with the mostly declining trend, in the downwind directions of the cities may imply an urban influence in precipitation associated with the increased anthropogenic emissions due to expansion of the urban areas and the increase of population. However, the large spatiotemporal variability of precipitation and the lack of statistical significance in the vast majority of the trends do not allow the extraction of safe conclusion concerning the aerosol-precipitation interactions around Indian cities.
\end{abstract}

\section{Introduction}

Rainfall is a key physical process that transports water from the atmosphere back to Earth's surface and links weather, climate, and hydrological cycle $[1,2]$. Especially for India, precipitation has serious importance in the regional climate, annual crop, food grains, and local economy and, therefore, analysis of the long-term trends in precipitation was the subject of numerous studies [3-5]. Duhan and Pandey [5] analyzed 102 years of precipitation records in central India (Madhya Pradesh) founding a spatial-averaged decreasing trend of $-2.59 \%$, with a maximum decrease of $\sim-12 \%$, but only 3 out of the 45 stations exhibited significant decreasing trend in annual precipitation. However, pronounced spatiotemporal differences were observed between the 45 stations on seasonal basis. Analysis of 100 years of surface rainfall observations over India suggested that the mean monsoon rainfall has not been significantly changed, but several locations across the country exhibited an increasing trend in heavy rainfall $(>70 \mathrm{~mm} /$ day $)$ during the summer monsoon season [6]. Furthermore, the increase in extreme rainfall (>120 mm/day) events during the Indian summer monsoon (ISM) is particularly pronounced during the last 50 years [7]. The extreme rainfall events analysis by Malik et al. [8] suggested that ISM exhibits characteristically different patterns in the year 2000 as compared to the period 19512000 with an increase in magnitude and frequency of extreme rainfall events and a decline in moderate ones. In contrast, Guhathakurtha et al. [9] noted decreasing trends in the frequency of monsoon rainy days in most parts of the country by examining changes in extreme rainfall events over India during the period 1901-2005. Similarly, Dash et al. [10] found 
a significant decrease in the frequency of moderate and low rainy days over India during the last half century. In synopsis, the precipitation fluctuations in India are largely random over the century, with no systematic change detectable on either an annual or a seasonal scale [11].

Basistha et al. [4] noted main causes of precipitation fluctuations in India, including the global and/or regional climate change implying a weakening monsoon circulation, land use land cover (LULC) changes corresponding to reduction in forest cover and increasing irrigated agriculture, and the increasing trend of anthropogenic aerosol and pollution levels. Bawiskar [12] analyzed sixty years (1948-2007) of daily temperature and wind datasets during premonsoon season (March-May) and observed a significant decrease in temperature gradient between Indian landmass and adjoining oceanic regions as a result of global warming. This decreasing trend directly affects the kinetic energy and cyclonic circulation over the area and can weaken the monsoon circulation in the lower troposphere. On the other hand, Rosenfeld [13] suggested that urban aerosols and anthropogenic pollution may reduce, or even vanish, the precipitation from clouds that have temperature of about $-10^{\circ} \mathrm{C}$ at their tops in a moderately convective situation, while they may support the occurrence of heavier precipitation in a more convective and humid environment. Aerosol particles from both natural and anthropogenic sources are among the factors that could contribute to enhanced warming and precipitation redistribution over India [14, 15].

Atmospheric aerosols may affect precipitation through their direct, semidirect, and indirect effects in solar radiation and clouds. The former mostly acts to suppress precipitation by decreasing the amount of ground-reaching solar radiation, and, hence, reducing the heat availability for evaporating water and energizing convective rain clouds. The second is defined by the strong absorbing capability of the carbonaceous aerosols, which absorb solar radiation and heat the atmosphere, leading to stabilization of the lower troposphere and suppression of convective clouds. Besides these effects, aerosols can also have important microphysical effects on clouds and precipitation through their influence on cloud drop nucleation (indirect effect), which affects cloud lifetime, cloud albedo, and precipitation $[16,17]$. Anthropogenic aerosols serve as small cloud condensation nuclei (CCN), which may slow down cloud-drop coalescence as well as the ice precipitation and prolong the time required in conversion of cloud water into precipitation [18]. Givati and Rosenfeld [19] quantified the microphysical effects of air pollutants on precipitation in a regional scale and found a decrease of 15$25 \%$ in orographic precipitation in the downwind direction of the pollution sources. Similarly, Rosenfeld et al. [20] highlighted the role of air pollution in the loss of water resources in hilly areas and suggested a 30-50\% decrease in precipitation during hazy conditions at the mountains. Borys et al. [21, 22] provided evidence on suppression of precipitation in winter orographic clouds due to atmospheric pollutants that increase the CCN concentration leading to formation of smaller cloud droplets. The reduced drop size caused smaller fall velocities and smaller amounts of snowfall. Furthermore, Rosenfeld et al. [23] suggested that increase in aerosol concentration beyond a threshold would decrease the vigor of convective clouds because of both direct and indirect microphysical effects. On the other hand, several studies [2426] suggested reduction in ground-reaching solar radiation, evaporation, and daytime temperature over heavily polluted areas due to formation of fog-like haze associated with increased anthropogenic pollutants. However, to establish any link between aerosols and precipitation over India is a real challenge, since changes in ambient meteorological conditions, in intraseasonal monsoon variability, and in land cover and normalized difference vegetation index (NDVI) can also influence precipitation [27-31]. On the other hand, several studies [32-35] observed a reverse effect, that is, enhancement of precipitation with aerosols.

Furthermore, land use changes affect several atmospheric properties and processes, such as boundary layer dynamics [36], convection [37], mesoscale circulations [38], cloud properties [39], and precipitation [40-42]. A significant impact of urbanization on the spatiotemporal patterns of precipitation was also highlighted in the literature [43-45]. India has witnessed an explosive growth of population $(0.3$ billion in the year 1950 to 1.04 billion in the year 2002) accompanied by uncontrolled urbanization over the last five decades. The population growth is mainly detected in urban areas due to the large-scale migration of rural population. Around urban areas, natural landscapes have been modified by artificial surfaces during construction, which are more capable of storing solar energy and converting it to sensible heat resulting in an increase of temperature (Urban Heat Island, [46, 47]) compared to surrounding environments. Kaufmann et al. [48] analyzed the impact of urbanization in the Pearl River Delta, China, and suggested more than 300\% increase in urban areas, which were strongly related with reduction in rainfall causing dry winters over the region. To this respect, Lee et al. [49] suggested a significant weakening of ISM due to an increase in surface albedo and reduction in surface roughness. Modeling investigations by the same authors show that monsoon circulation and rainfall are being influenced by the major modifications of the biosphere in the Indian subcontinent, mainly caused by surface energy balance altering, the planetary boundary layer motion fields, moisture convergence, and hydrological cycle. More recently, Kishtawal et al. [50] found a significant increasing trend in the frequency of heavy rainfall over urban regions in India during the monsoon season, with this increasing trend to be more pronounced over areas with faster urbanization.

In the present study, we have analyzed the long-term (1951-2007) variations and trends in precipitation (rainfall amount and number of rainy days) over six Indian cities (namely, Delhi, Hyderabad, Bangalore, Kanpur, Nagpur, and Jaipur). In order to examine possible urban aerosol-pollution forcing on precipitation amount and trends, the analysis has been performed over the upwind and downwind directions of each city during the rainy monsoon (June-September) period. Moreover, extensive literature survey and discussions are provided for possible linkage of the long-term precipitation trends with the increasing anthropogenic aerosols and LULC changes around the urban centers. 
TABLE 1: Upwind and downwind grids around the six selected locations along with the dominant surface wind flow and the dispersion of pollutants during the monsoon period.

\begin{tabular}{lcccc}
\hline Location & Upwind grid & Downwind grid & Surface wind & Dispersion of pollutants \\
\hline Delhi & $27.5^{\circ} \mathrm{N}-78.5^{\circ} \mathrm{E}$ & $29.5^{\circ} \mathrm{N}-76.5^{\circ} \mathrm{E}$ & Mostly from southeast & Mostly to northwest \\
Hyderabad & $16.5^{\circ} \mathrm{N}-77.5^{\circ} \mathrm{E}$ & $18.5^{\circ} \mathrm{N}-79.5^{\circ} \mathrm{E}$ & Southwest & Northeast \\
Kanpur & $25.5^{\circ} \mathrm{N}-81.5^{\circ} \mathrm{E}$ & $27.5^{\circ} \mathrm{N}-79.5^{\circ} \mathrm{E}$ & Mostly from southeast & Mostly to northwest \\
Jaipur & $25.5^{\circ} \mathrm{N}-76.5^{\circ} \mathrm{E}$ & $27.5^{\circ} \mathrm{N}-74.5^{\circ} \mathrm{E}$ & Mostly from southeast & Mostly to northwest \\
Nagpur & $20.5^{\circ} \mathrm{N}-78.5^{\circ} \mathrm{E}$ & $22.5^{\circ} \mathrm{N}-80.5^{\circ} \mathrm{E}$ & Southwest & Northeast \\
Bangalore & $11.5^{\circ} \mathrm{N}-76.5^{\circ} \mathrm{E}$ & $13.5^{\circ} \mathrm{N}-78.5^{\circ} \mathrm{E}$ & Southwest & Northeast \\
\hline
\end{tabular}

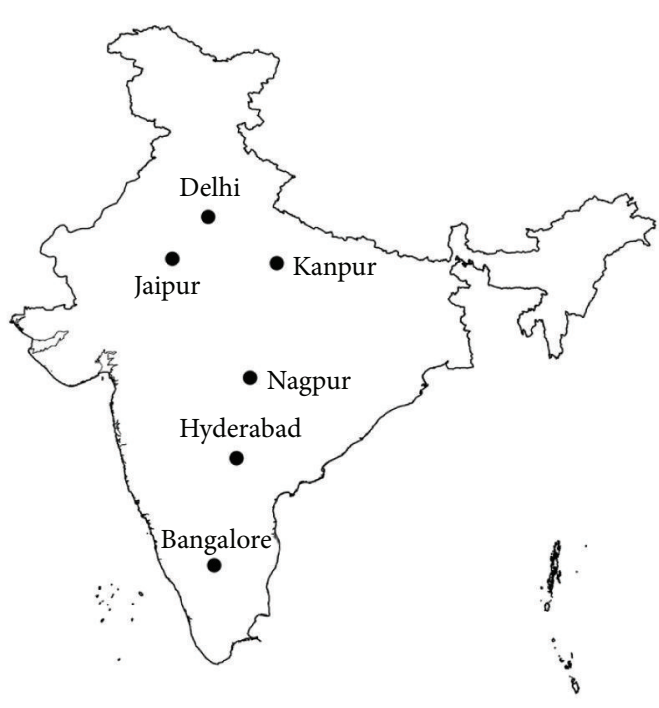

(a)

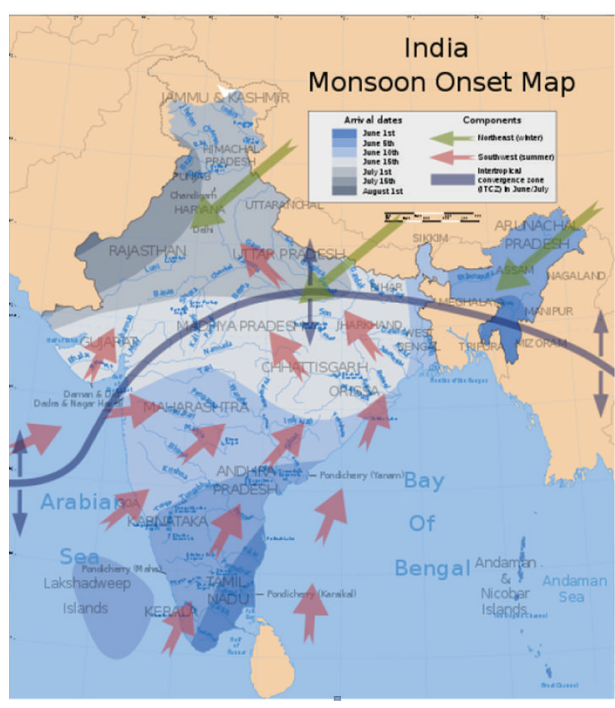

(b)

FIGURE 1: Locations of the 6 Indian urban cities used in the analysis (a) and monsoon onset map (b) obtained from http://en.wikipedia.org/ wiki/File:India_southwest_summer_monsoon_onset_map_en.svg.

\section{Selected Sites and Climatology}

Six urban locations at different regions of India have been considered for the analysis (Figure 1(a)). Except from the variations in the land use, topography characteristics, and meteorological conditions, the selected urban sites present large differences regarding the monsoon onset as shown in Figure 1(b). This figure shows shifting of the intertropical convergence zone (ITCZ) northwards during the summer monsoon season. The winds are from southwest (except the northwestern part of the country), while the monsoon rainfall affects primarily (beginning of June) the southeastern Indian regions and by the end of July has affected the whole territory except from the northwestern regions (Thar desert and Indian Trans-Himalaya). Detailed information about climatology, land use, and specific characteristics of the different Indian regions can be found in Ramachandran and Cherian [51]. In order to qualitatively assess the urban forcing in precipitation changes, upwind and downwind pixels around the six cities are selected based on the dominant monsoon surface wind flow (Table 1). The sites located in central-south India (Hyderabad, Nagpur, and Bangalore) are influenced by the southwest monsoon flow (Arabian Sea branch; see Figure 1(b)), while the rest sites (Delhi, Jaipur, and
Kanpur) are mainly influenced by the Bay of Bengal branch and the dominant surface winds are from east-southeast direction (Figure 1(b)).

2.1. Delhi. Delhi is the capital of India situated in the northern part of the country $\left(28.38^{\circ} \mathrm{N}, 77.12^{\circ} \mathrm{E}, 218 \mathrm{~m} \mathrm{ASL}\right)$. It is the largest center of small industries and main commercial center in northern India. The city is densely populated and has a large number of automobiles, thus adding additional loading of industrial and urban emissions, in addition to the desertdust transport during premonsoon and monsoon [52]. The climate of the area is monsoon-influenced subtropical with large variations in temperature and precipitation between winter and summer seasons. The prevailing winds are mainly easterly, northerly and northwesterly during the summer season [53].

2.2. Hyderabad. Hyderabad $\left(17.47^{\circ} \mathrm{N}, 78.42^{\circ} \mathrm{E}, 547 \mathrm{~m}\right.$ ASL) is the fifth largest city in India with $\sim 5.5$ million inhabitants and is also considered as one of the most polluted due to population growth and associated anthropogenic activities observed during the last decades. The decennial growth of population (1981-91) is 39.7\% against the growth rate of 
$24.2 \%$ for the state. As a consequence, the traffic density has been increased contributing 75\% of all sources of air pollution in Hyderabad [54]. Additionally, dust transported during premonsoon and monsoon, crop residue burning in autumn, and forest fires in the dry period of the year affect the atmosphere over Hyderabad [55-57]. The climate of the region is semiarid with a total rainfall amount of $\sim 700 \mathrm{~mm}$ occurring mostly during the monsoon season (June-September) under the influence of the strong southwesterly winds.

2.3. Bangalore. Bangalore $\left(12.58^{\circ} \mathrm{N}, 77.38^{\circ} \mathrm{E}, 920 \mathrm{~m} \mathrm{ASL}\right)$ is located in the Deccan Plateau in the southern part of India, which is influenced by the Arabian Sea and the Bay of Bengal. Due to its high elevation, Bangalore usually enjoys salubrious climate throughout the year, although freak heat waves can make life very uncomfortable during summer months. The coolest month is January with an average low temperature of $15.1^{\circ} \mathrm{C}$ and the hottest month is April with an average high temperature of $33.6^{\circ} \mathrm{C}$. Bangalore receives rainfall from both the northeast and the southwest monsoons and the wettest months are September, October, and August [58]. The climate of the area is classed as the seasonally dry tropical savanna climate with four seasons.

2.4. Kanpur. Kanpur $\left(26.28^{\circ} \mathrm{N}, 80.24^{\circ} \mathrm{E}, 142 \mathrm{~m}\right.$ ASL $)$ lies in the central part of the Indo-Gangetic Plains and is one of the most polluted cities in India [59]. It is characterized by a very hot summer and cold winter; the temperature during summer goes up to $40^{\circ} \mathrm{C}$ and in winter it is dropped below $0^{\circ} \mathrm{C}$. Kanpur is the 9th most populous city in India and is highly congested, overcrowded and with high aerosol levels [60].

2.5. Jaipur. Jaipur, the capital city of Rajasthan state $\left(26.53^{\circ} \mathrm{N}\right.$, $75.50^{\circ} \mathrm{E}, 432 \mathrm{~m} \mathrm{ASL}$ ) located in the northwestern India (close to Thar desert), is one of the fastest growing cities in the country. The climate of the area is extremely hot with humid summers and chilly winters, while aerosols of desert origin dominate [61]. During the monsoon months there are frequent heavy rains and thunderstorms, but flooding is not common. The winter months of November to February are mild and pleasant, with average temperatures in the 15$18^{\circ} \mathrm{C}$ range and little humidity. However, there are occasional cold waves that lead to temperature near freezing. Monsoon usually starts in the third week of July, but the area does not experience much of rainy days due to its semiarid climate.

2.6. Nagpur. The city of Nagpur $\left(21.09^{\circ} \mathrm{N}, 79.09^{\circ}, 310 \mathrm{~m}\right.$ ASL $)$ located in the central India has been classified under dry or semihumid climate throughout the year except the monsoon months of June-September [62]. The climate witnesses a very hot weather during April-June, while in winter the temperature hovers around $12^{\circ} \mathrm{C}$ and, sometimes, even dips down to zero. The rainfall is driven by the south-westerly monsoon winds. The mean annual rainfall ranges between $1000 \mathrm{~mm}$ and $1300 \mathrm{~mm}$, of which about $80 \%$ is received during monsoon.

\section{Dataset and Methodology}

The daily gridded rainfall data at $1^{\circ} \times 1^{\circ}$ spatial resolution from India Meteorological Department (IMD) was used [63]. The IMD product uses gauge data from 1803 stations to estimate accumulated rainfall in the 24 hours ending 08:30 IST (03:00 UTC) during the period 1951-2007. IMD uses the Shepard [64] interpolation technique for gridding data from individual stations over the Indian subcontinent $\left(6.5^{\circ} \mathrm{N}\right.$ to $37.5^{\circ} \mathrm{N}, 66.5^{\circ} \mathrm{E}$ to $\left.101.5^{\circ} \mathrm{E}\right)$. In this method, the interpolated values are computed from a weighted sum of the observations. More specifically, for a given grid point, the search distance is defined as the distance from this point to a given station, while the interpolation is restricted to the radius of influence. For search distances equal to or greater than the radius of influence, the grid point value is assigned a missing code when there is no station located within this distance. More details about IMD gridded rainfall datasets have been described elsewhere [63]. In the present work, we used the gridded points over the 6 urban centers and the rainfall data in the downwind and upwind directions from the stations, based on climatology of surface wind direction during the rainy monsoon season. It should be noted that the dominant surface wind flow may differentiate during the drought monsoon years, as a response of anomalies in pressure pattern [65], without being considered in the analysis. The upwind and downwind grids remain the same during the whole study period (Table 1), and this may affect the rainfall amount and trends. Thus, for a more detailed analysis, except of the higher spatial resolution grid around the urban areas, the upwind and downwind regions have to account for the daily surface-wind flow. Furthermore, the gridded daily rainfall data over Indian region were analyzed to identify the number of rainy days for each year at the selected stations and in the upwind and downwind directions. The rainy days were detected by noting the rainfall values and the days with rainfall values above " 0 " were considered as rainy. The variability in precipitation at any grid point depends on large-scale dynamics and the regional/local forcing as well. Therefore, a higher resolution rainfall dataset, like APHRODITE $\left(0.25^{\circ} \times 0.25^{\circ}\right.$ and $0.5^{\circ} \times 0.5^{\circ}$ resolution), may be more effective in capturing the fluctuation in precipitation due to changes in local emissions and LULC changes [66]. Qualitative comparison between the two gridded databases (IMD and APHRODITE) has been recently performed by Krishnan et al. [67], who found an overall satisfactory agreement concerning the spatial distribution of the trends in rainfall rate over India during the summer monsoon (JJAS) season in the period 1951-2007. We may also point out that the aerosol data is not available in such a high spatial resolution similar to APHRODITE data sets.

\section{Results}

4.1. Regional Monsoon Meteorology. The ISM is characterized by south-westerly winds in the lower troposphere affecting the most part of the Indian subcontinent and adjoining oceanic regions from June to September being the main source of precipitation over the whole south Asia. This 


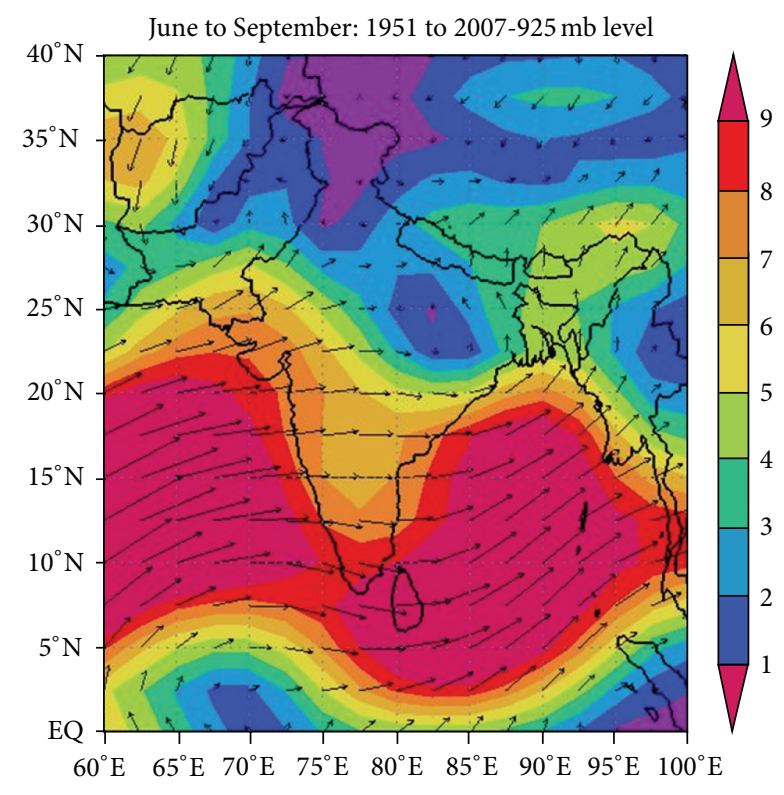

$\longrightarrow$

FIGURE 2: NCEP/NCAR reanalysis mean vector wind composite at $925 \mathrm{mb}$ level for Indian summer monsoon (June-September) during 1951-2007.

system is part of a large-scale circulation pattern, which develops in response to the thermal gradients between the warm Asian continent in the north and cooler Indian Ocean in the south. A center of low-pressure system develops over the western part of India during the summer season, because of the intense heating of the landmass, while high pressure develops over the relatively cooler Indian Ocean. This pressure gradient carries moisture oceanic air masses in to mainland, which are released as precipitation [68].

The mean (1951-2007) composite vector wind at 925-mb level from NCEP/NCAR reanalysis website (http://www.cdc .noaa.gov/cgi-bin/data/composites/printpage.pl/) is shown in Figure 2 during the monsoon period. The mean wind direction is shown by the arrows, while the wind speed depends on arrow length and is color scaled. The winds are mainly south-westerly over the Bay of Bengal (BoB) and the Arabian Sea (AS), shifting towards west over the Indian mainland. The ISM has two branches, (a) the AS branch and (b) the BoB branch. The former dominates the weather scenes in central and peninsular India, while the latter controls the weather scenes in Bangladesh, northeastern India, IndoGangetic Plains (IGP), and the southern slopes of Himalayas. The wind speed is larger over sea (above $9 \mathrm{~ms}^{-1}$ ), while lower speed intensities are observed in the central and northern India. The southern studied locations, that is, Bangalore, Hyderabad, and Nagpur, are influenced more by the abundant moisture from the south-westerly winds than those located in IGP, that is, Delhi and Kanpur, and as a consequence, the monsoon precipitation is larger over southern India and decreases gradually towards the northern parts of the country. This fact may also redistribute the rainfall over the study regions between intense and weak monsoon years.
4.2. Trends in Total Number of Rainy Days. Figure 3 shows the multidecadal trend (1951-2007) in total number of rainy days over the six Indian cities during summer monsoon; the mean number of rainy days is also shown in each panel. Overall, the analysis shows large heterogeneities in the number of rainy days as well as in the multidecadal variability and trends. Thus, Hyderabad, Kanpur, Jaipur, and Nagpur exhibit negative trends in the total number of rainy days; however, positive trends are observed for Delhi and Bangalore results that are in general agreement with those found by De and Prakas Rao [69]. Statistically significant trend at 95\% confidence level is shown only at Bangalore strongly influenced by the large peak in 2005. According to the analysis, the total number of rainy days suggests a $7.4 \%$ and $22.9 \%$ increase over Delhi and Bangalore; however, over Hyderabad, Jaipur, Kanpur, and Nagpur a decrease of $-10.4 \%,-10.5 \%,-7.1 \%$, and $-4.8 \%$, respectively is found. Large interannual variability in the total number of rainy days is observed over all cities attributed to intense and weak monsoon years, which may, in turn, cause significant anomalies in the aerosol field [31]. The large differences in the monsoon onset, duration, and intensity over Indian subcontinent (Figure 1(b)), along with the high spatial variation in the intensity of prolonged dry or drought conditions over the country are the main reasons for the different fluctuations in precipitation dataset over the different locations and, therefore, for the different trends [67]. However, in Bangalore these fluctuations are much smoother, due to its proximity to the AS and BoB, except an abnormal increase in rainy days up to 100 in 2005 . This extreme value, also detected in the rainfall amount (Figure 4), seems to be mostly attributed to topography and local forcing since in the upwind region of the city (Figure 10) the variability in rainfall is much more fluctuated with several peaks and gaps, on which the 2005 peak is not so intense. However, at the pixel over Bangalore, as well as in the downwind region, the precipitation exhibits an abnormal increase in 2005. The analysis reveals that the most rainy days are observed in Nagpur (88 \pm 9$)$ and Hyderabad $(73 \pm 9)$ corresponding to $\sim 72 \%$ and $\sim 60 \%$ of the total days during the monsoon season. On the other hand, the number of rainy days is less in Jaipur (50 \pm 10$)$, Delhi $(55 \pm 10)$, and Bangalore $(51 \pm 12)$.

Earlier studies suggested that tropospheric warming leads to enhancement of moisture content in the atmosphere, which is associated with an increase in heavy rainfall events $[50,70,71]$. Similarly, significant increasing trends in the frequency and magnitude of extreme rain events have been found over India; however, considerable decline was observed in the frequency of moderate events over central India during 1951-2000 monsoon season [7]. They also suggested a $10 \%$ increase in the level of heavy rainfall events per decade from 1951 to 2000, whereas the number of extreme rainfall events indicated an increase of more than double. Further study of the trends in rainy days with light, moderate, and heavy rainfall amount (not shown) also revealed large heterogeneities between the sites, with increasing, neutral, or decreasing trends, which were not statistically significant in the vast majority of the cases. The present analysis revealed an increasing trend of heavy rainfall events $(>25 \mathrm{~mm}$ ) over Bangalore (statistically significant) and Nagpur; however, Delhi, 


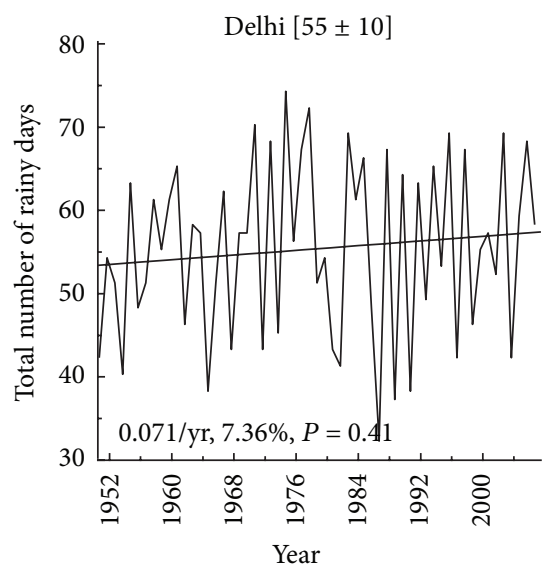

(a)

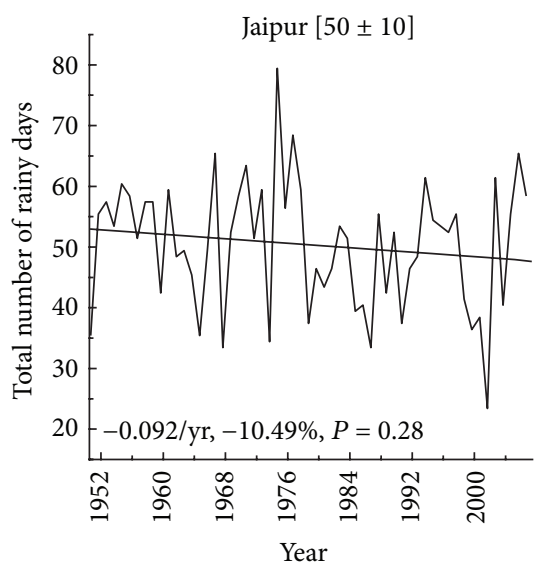

(d)

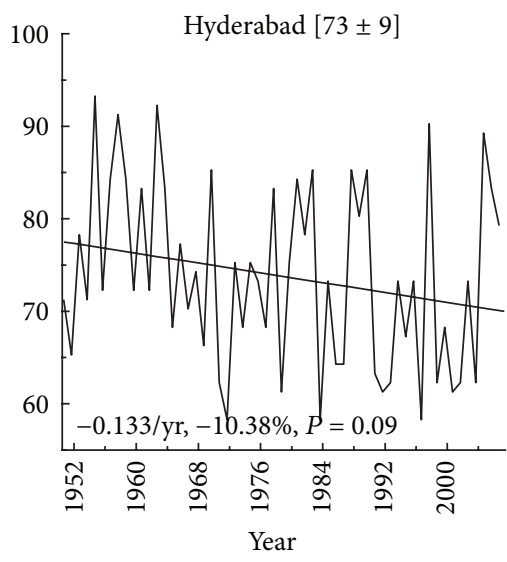

(b)

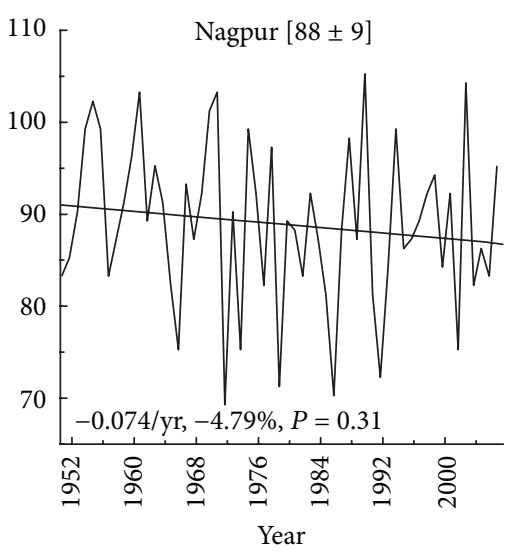

(e)

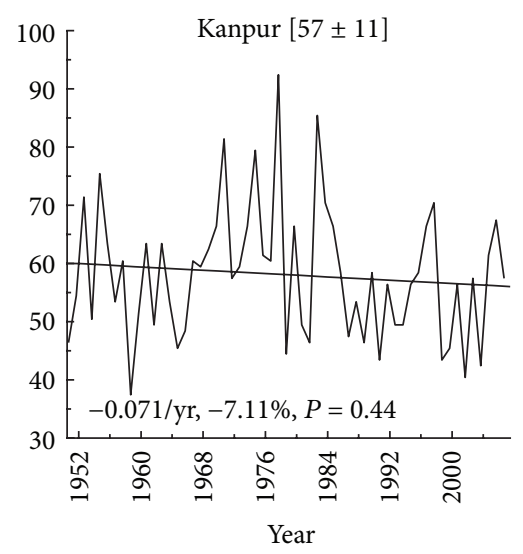

(c)

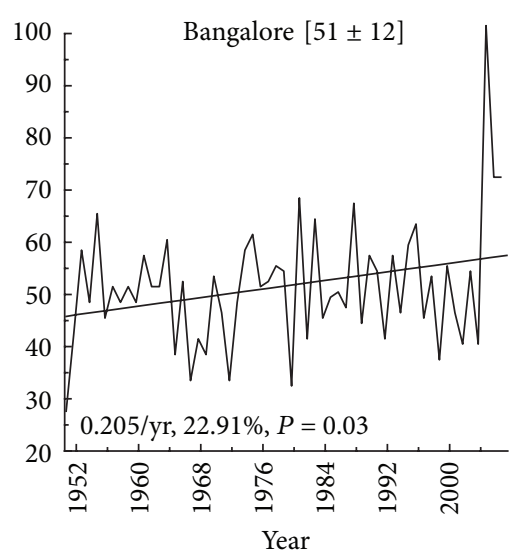

(f)

FIGURE 3: Long-term (1951-2007) trends of the total number of rainy days over Indian mega cities during southwest monsoon (JJAS) period. The mean values along the standard deviations as well as the results from the linear regression in the data series are given.

Jaipur and Kanpur suggested decreasing trends, whereas Hyderabad exhibited mostly neutral trend. The differences between the current results and those reported by Badarinath et al. [72] may be attributed to the different locations considered for the analysis, since we have not included any coastal urban center.

4.3. Trends in Seasonal Precipitation. The ISM rainfall is very important for the economic development, disaster management, and hydrological planning of the country, while the crop failure, drought, or famine due to deficient monsoon becomes very critical to local population [73]. The area-averaged rainfall over the whole country does not show any significant trend; however, large variations can exist at regional scale [74]. Figure 4 shows the trends in monsoonal rainfall over the 6 Indian cities during 1951-2007 accompanied with the mean seasonal rainfall amount and its standard deviation. Furthermore, the slope, the \% variation, and the $P$ value from the linear regressions are given at each panel. A general characteristic for all cities is the large yearto-year variability suggesting presence of intense and weak monsoon years [75]. Over Delhi, the seasonal rainfall ranges significantly, from a minimum of $\sim 150 \mathrm{~mm}$ to a maximum of $\sim 1000 \mathrm{~mm}$ (mean of $609 \pm 207$ ), while over Hyderabad it presents lesser variability ( $310 \mathrm{~mm}$ to $965 \mathrm{~mm}$ ) with similar mean value. Kanpur exhibits a mean of $705 \pm 245 \mathrm{~mm}$, while Jaipur and Bangalore present the lowest amounts of rainfall (about 485 and $415 \mathrm{~mm}$, resp.). The semiarid environment close to Thar desert is responsible for the low rainfall in Jaipur, while for Bangalore the main reason is the regional topography and the high mountains around the city able to receive the largest amounts of precipitation. Finally, over Nagpur the seasonal rainfall ranges from a minimum of $\sim 500 \mathrm{~mm}$ to a maximum of $\sim 1500 \mathrm{~mm}$. Furthermore, the multidecadal variability exhibits significant differences between the urban sites. Large spatial distribution in monsoon rainfall was also reported by Prasad et al. [29] over Indian subcontinent, while Gautam et al. [76] observed different trends in rainfall over northern India depending on month, for example, positive trend in June and negative for the rest of the monsoon (JulySeptember). Furthermore, no clear periodicity in the rainfall amount was found from the statistical analysis. On the other hand, negative trends in seasonal rainfall are observed over Delhi $(-21.3 \%)$, Hyderabad (-5.9\%), Kanpur (-14.6\%), and 

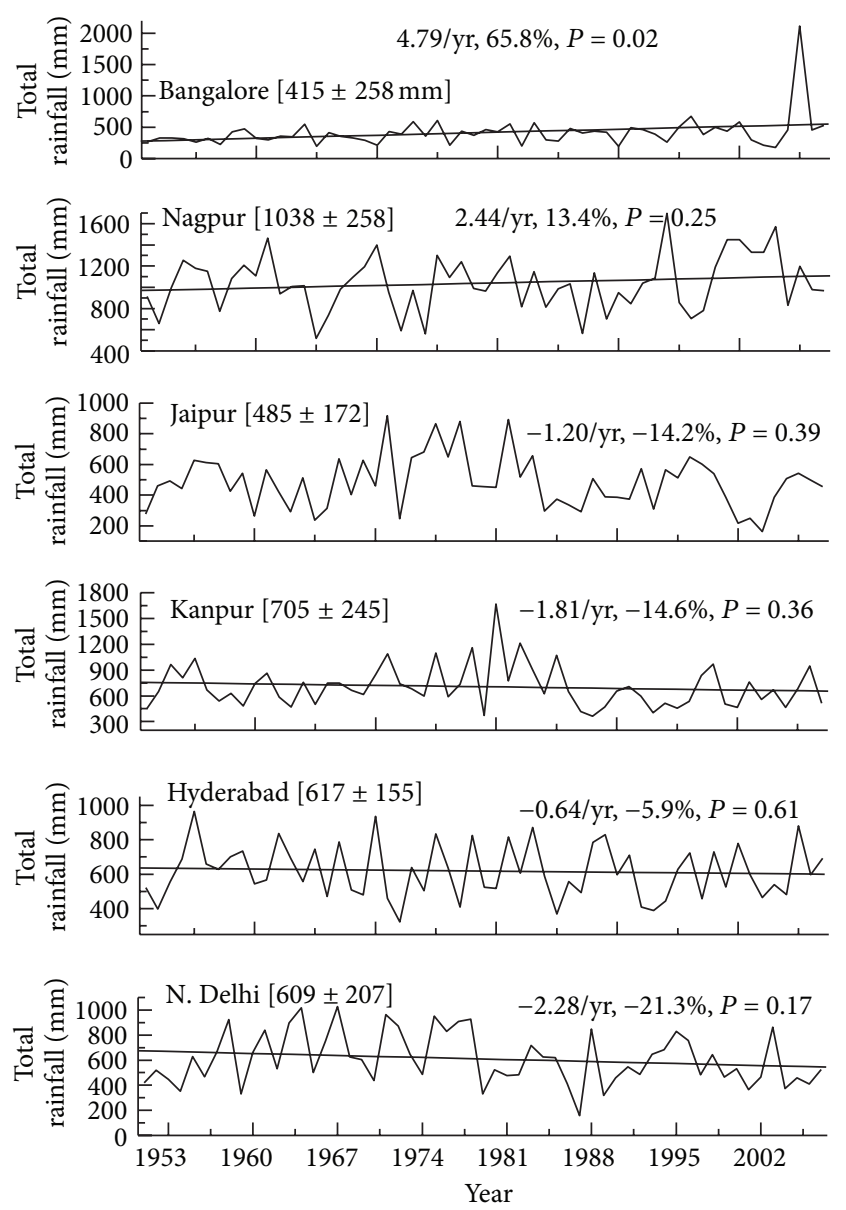

FIGURE 4: Trends in monsoonal rainfall amount (JJAS) over different Indian cities during 1951-2007. The mean values along the standard deviations as well as the results from the linear regression in the data series are given.

Jaipur (-14.2\%); however, Bangalore and Nagpur exhibit increasing trend in monsoon rainfall, corresponding to $65.8 \%$ and $13.4 \%$, respectively. Statistically significant trend is considered only in Bangalore, and influenced by the extreme value in 2005, which is even 3 times larger than the climatological mean. Similarly to our findings, De and Prakas Rao [69] observed increasing trend of rainfall over Bangalore. The rainfall trends in Delhi and Nagpur seem not to coincide well with the trends in the rainy days, that is, decrease in rainfall and increase in rainy days for Delhi and the opposite for Nagpur. This inconsistency, although can be partly explained via variations and trends in the rain intensity, may be only pixel-dependent, since in the upwind and downwind regions of both cities (Figures 5 and 9) the two parameters covary.

4.4. Trends in Number of Rainy Days and in Seasonal Precipitation at Upwind and Downwind Grids. According to Rosenfeld [13] and Toon [77] urban and industrial air pollution suppresses precipitation-forming process in convective clouds. Furthermore, Borys et al. [21] suggested that even a little amount of anthropogenic sulfate aerosols may

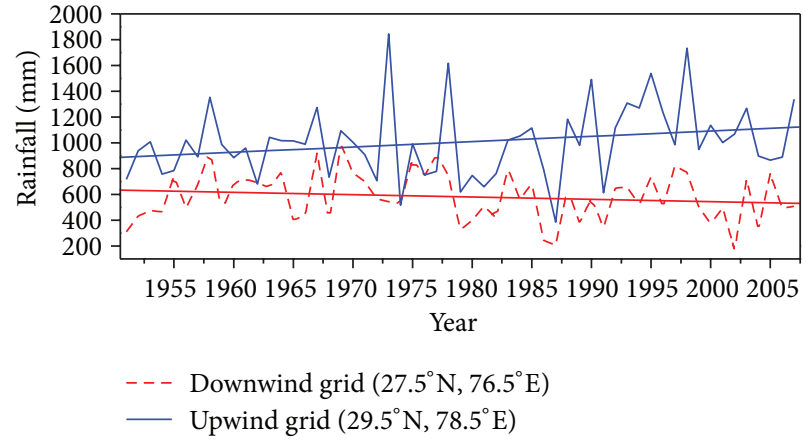

(a)

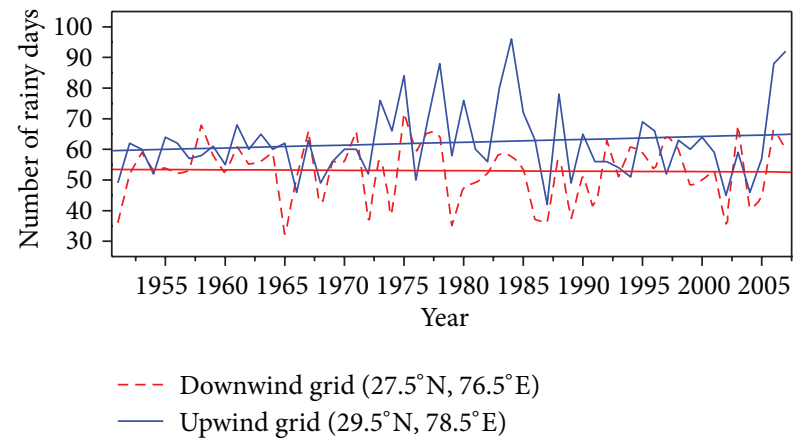

(b)

FIGURE 5: Long-term (1951-2007) trends of (a) monsoonal rainfall and (b) total number of rainy days over downwind and upwind grids around Delhi during the southwest monsoon (JJAS) period.

reduce the orographic snowfall rate by up to $50 \%$ in the Colorado City Mountains. The most vulnerable regions for precipitation suppression effects are those that are in the downwind direction to the populated urban centers [19]. Thus, the precipitation was found to decrease over hills and mountains downwind of major coastal urban areas in California and Israel, while the suppression rate was found to be $15 \%-25 \%$ of the annual precipitation $[19,78]$. In this respect, we further examine the trends in rainfall and number of rainy days in the upwind and downwind directions of the selected urban centers. It is to be noted that due to large spatial distribution of precipitation, the values may differentiate even in nearby pixels, so a qualitative rather than quantitative analysis can be revealed from the following figures.

Figure 5 shows the long-term (1951-2007) trends of (a) rainfall and (b) total number of rainy days at downwind and upwind grids around Delhi during the monsoon (JJAS) period. The seasonal rainfall exhibits a negative trend over the downwind grid. However, the total number of rainy days remains nearly constant over the region. Contrary to the downwind direction, the upwind one shows a pronounced increasing trend in both the seasonal rainfall and total number of rainy days. Note also the significant larger precipitation amount and number of rainy days in the upwind direction. Therefore, there is evidence that the large variation in rainfall, total number of rainy days, and their associated trends, even in a $2^{\circ} \times 2^{\circ}(\sim 200 \times 200 \mathrm{~km})$ region, may be forced by 


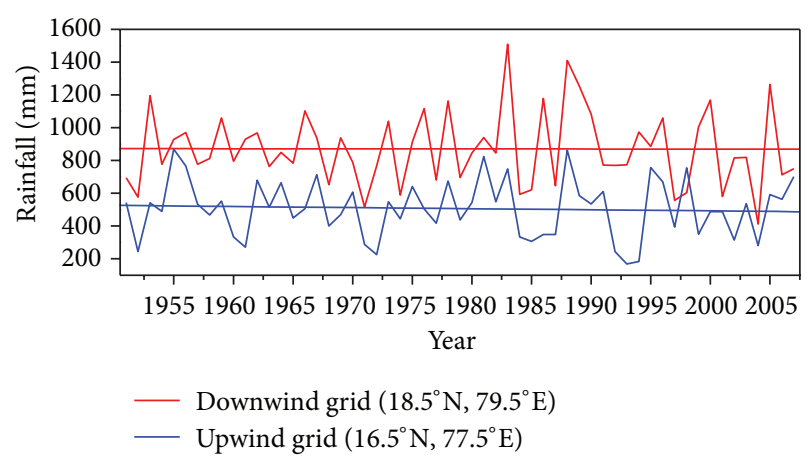

(a)

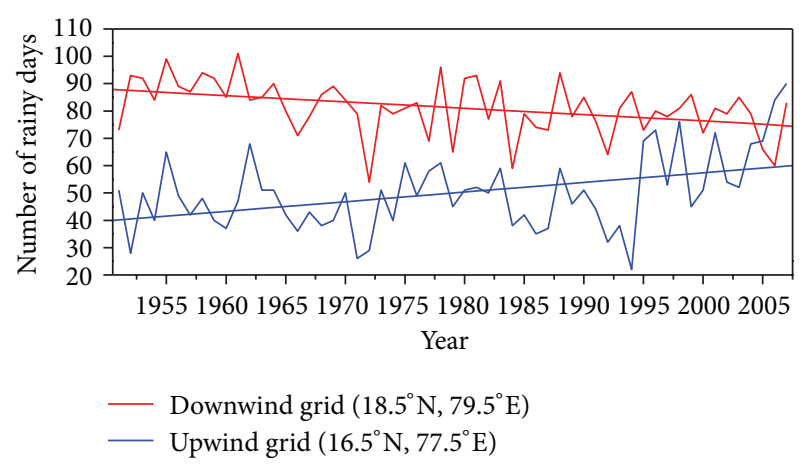

(b)

FIgURE 6: Same as in Figure 5 but for Hyderabad.

the urbanized area and the local emissions of aerosols and pollutants that suppress precipitation. These results are rather contradictory to those found by Kishtawal et al. [50] who reported an increase in heavy rainfall due to urbanization, since in our case no statistically significant difference was found in the trends of rainfall and number of rainy days.

More or less similar decreasing trends of seasonal rainfall and total number of rainy days at downwind grid of the cities are observed for Hyderabad (Figure 6), Kanpur (Figure 7), Jaipur (Figure 8), and Nagpur (Figure 9). However, the trends in both rainfall and total number of rainy days in the downwind directions present significant variability, since the precipitation is a strong function of the local and regional topography, the synoptic meteorology, and wind speed. More specifically, Hyderabad presents a neutral variation in rainfall amount (for downwind pixel), but a pronounced decreasing trend in the number of rainy days. Kanpur shows similar to Hyderabad trends in rainfall and number of rainy days for the downwind pixel, while Jaipur exhibits neutral variation in the number of rainy days and a slight decrease in rainfall. On the other hand, in Nagpur the slight decreasing trend in the number of the rainy days was mostly pronounced for the heavy rainfall amounts (not shown), while a similar decreasing trend is observed in rainfall. In contrast, Bangalore exhibits slight increasing trend in seasonal rainfall and rainy days at the downwind direction, mainly driven by the large rainfall amount in 2005 (Figure 10). However, the difference in rainfall amount between upwind and downwind pixels around Bangalore is about four-fold, or even more

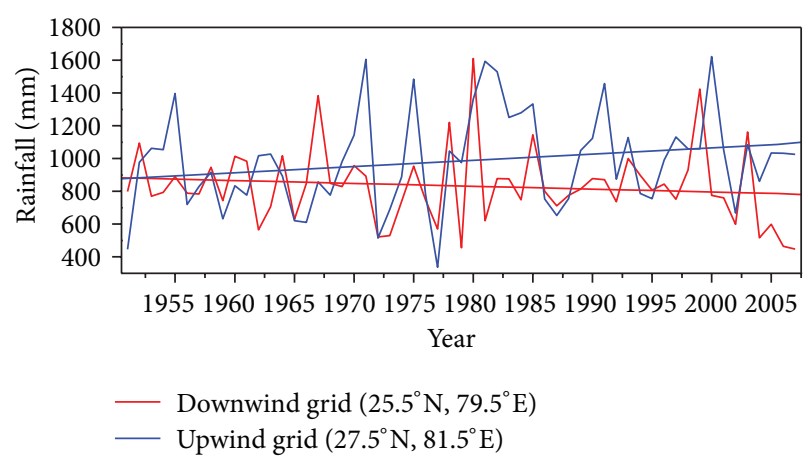

(a)

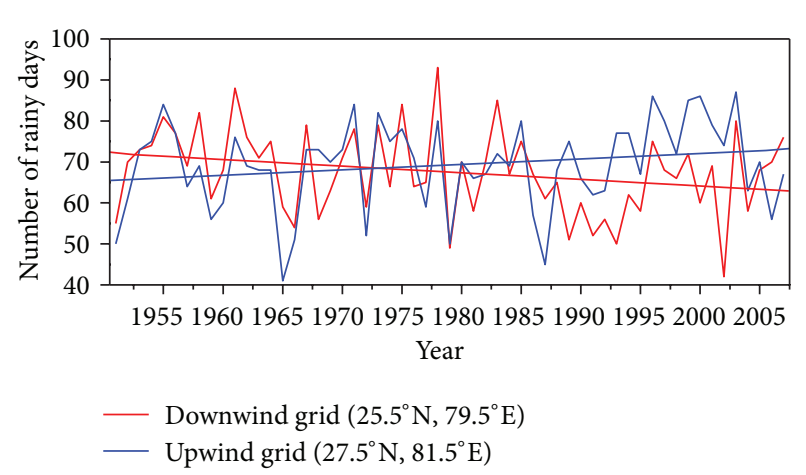

(b)

FIgURE 7: Same as in Figure 5 but for Kanpur.

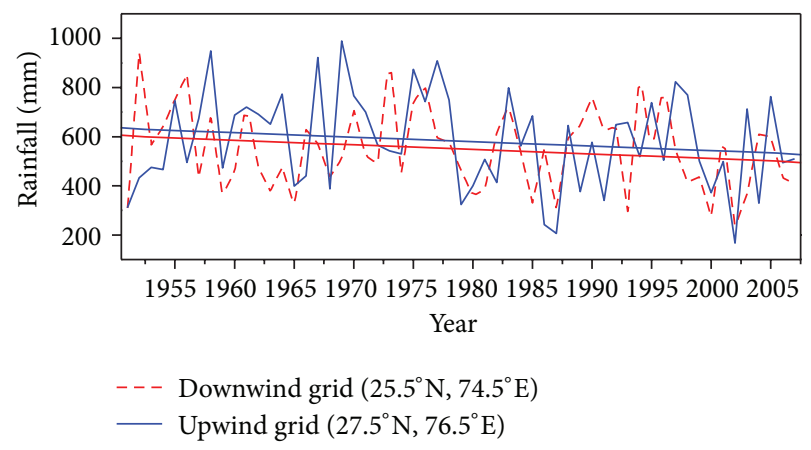

(a)

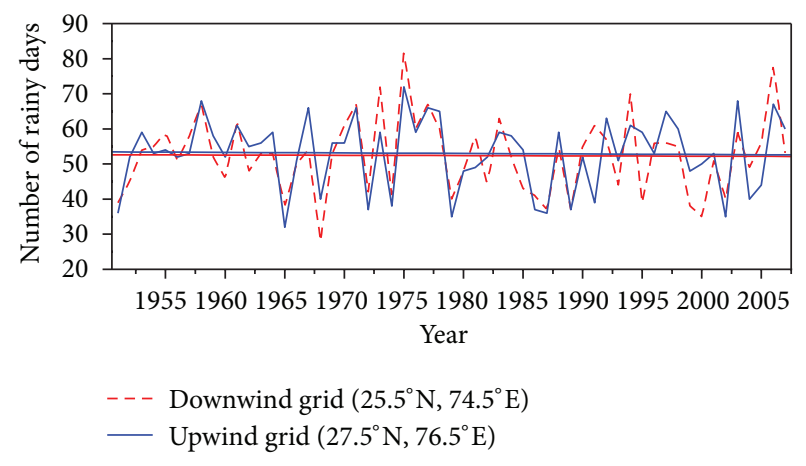

(b)

FIgURE 8: Same as in Figure 5 but for Jaipur. 


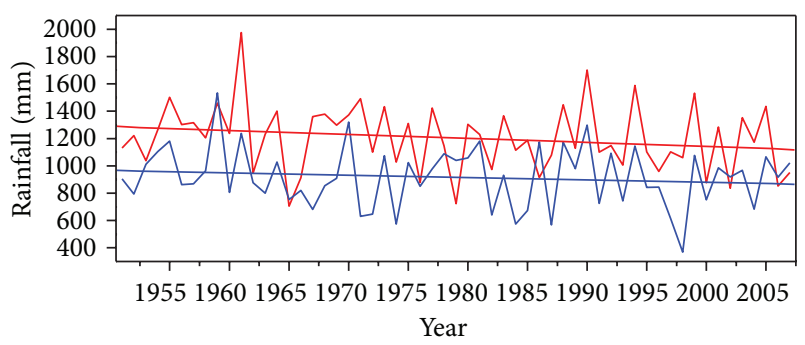

- Downwind grid $\left(22.5^{\circ} \mathrm{N}, 80.5^{\circ} \mathrm{E}\right)$

- Upwind grid $\left(20.5^{\circ} \mathrm{N}, 78.5^{\circ} \mathrm{E}\right)$

(a)

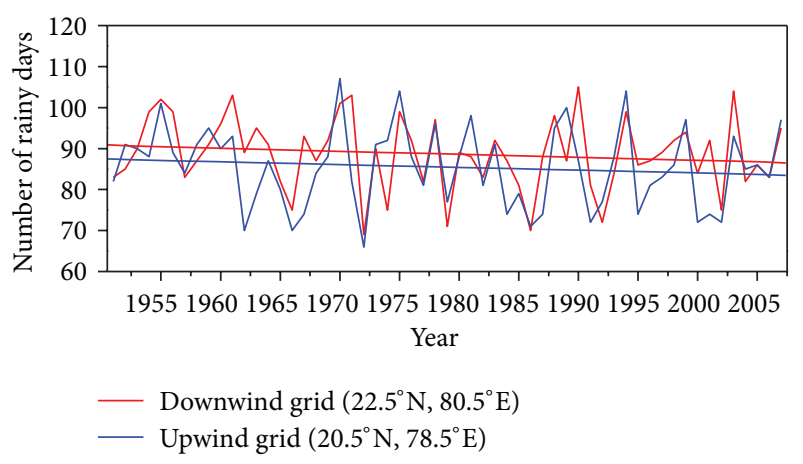

(b)

FIgURE 9: Same as in Figure 5 but for Nagpur.

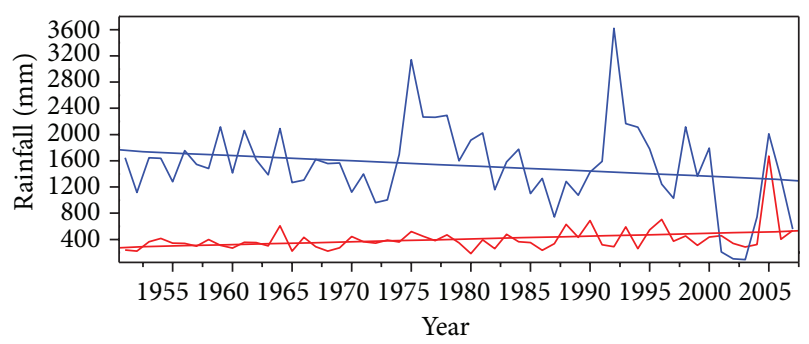

- Downwind grid $\left(13.5^{\circ} \mathrm{N}, 78.5^{\circ} \mathrm{E}\right)$

- Upwind grid $\left(11.5^{\circ} \mathrm{N}, 76.5^{\circ} \mathrm{E}\right)$

(a)

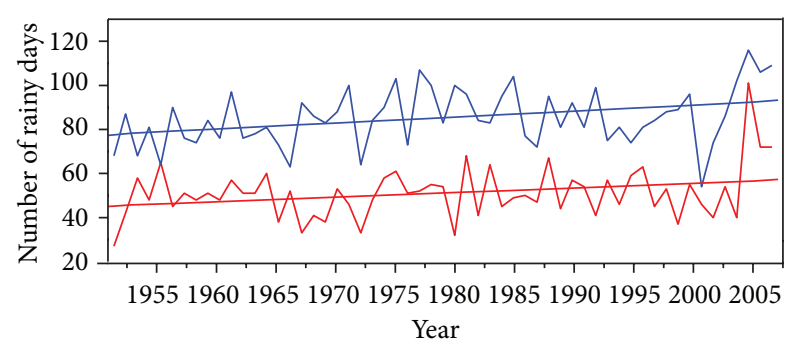

- Downwind grid $\left(13.5^{\circ} \mathrm{N}, 78.5^{\circ} \mathrm{E}\right)$

— Upwind grid $\left(11.5^{\circ} \mathrm{N}, 76.5^{\circ} \mathrm{E}\right)$

(b)

FIGURE 10: Same as in Figure 5 but for Bangalore.
TABLE 2: Percentage (\%) variation in rainfall and number of rainy days in upwind (up) and downwind (down) directions of the 6 Indian cities. The statistically significant trends in $95 \%$ confidence level are defined via bold.

\begin{tabular}{lcccc}
\hline \multirow{2}{*}{ Station } & \multicolumn{2}{c}{ Rainfall } & \multicolumn{2}{c}{ Number of rainy days } \\
& \multicolumn{2}{c}{ Direction } & \multicolumn{2}{c}{$\begin{array}{c}\text { Direction } \\
\end{array}$} \\
up & down & up & down \\
\hline Delhi & 23.41 & -17.84 & 8.56 & -1.60 \\
Hyderabad & -7.40 & -0.40 & $\mathbf{4 0 . 1 6}$ & $-\mathbf{1 6 . 2 7}$ \\
Kanpur & 21.95 & 11.88 & 10.94 & -13.59 \\
Jaipur & -17.84 & -19.23 & -1.62 & -0.87 \\
Nagpur & -10.71 & -13.60 & -4.54 & -4.76 \\
Bangalore & -29.38 & $\mathbf{6 0 . 7 4}$ & $\mathbf{1 7 . 7 7}$ & $\mathbf{2 2 . 8 5}$ \\
\hline
\end{tabular}

at specific years, a fact that indicates a strong influence of the regional topography also. Similar feature, that is, much lower values at the downwind pixel, is also observed for the total number of rainy days. On the other hand, increasing trends of the total number of rainy days at upwind grid of the cities are observed over Hyderabad, Kanpur, and Bangalore, while Nagpur and Jaipur exhibit slightly negative or neutral trends. Table 2 summarizes the \% variations in rainfall and number of rainy days as obtained from the linear regression analysis. Despite the significant differences between the sites, the results show that the trends in rainfall and total number of rainy days at the downwind directions are mostly negative, while higher precipitation at the upwind directions occurs.

\section{Discussion}

This section aims to associate the multidecadal variability in precipitation amount between upwind and downwind areas around the cities with trends in anthropogenic aerosols and pollutants, the growing rate of population and LULC changes due to urbanization. Several ground-based and satellite observations highlight an increase in aerosol loading over Indian subcontinent, especially for the anthropogenic component, during the last decades $[27,79,80]$. This is a direct consequence of the increase in population density [81], demands for energy, urbanization, and industrialization being a major reason for the continuation of the solar dimming phenomenon $[72,82]$ and the formation of atmospheric brown clouds [83]. Increasing trends in aerosol optical depth (AOD) during the last decade have been observed over Delhi [84], Kanpur [85], Hyderabad [86], Trivandrum [87], Pune [88], and several other locations in India [51]. However, the increasing AOD trends exhibited significant spatiotemporal heterogeneity over Indian mainland and adjoining oceanic regions as revealed from the aforementioned studies. The main finding is that a large increase in anthropogenic AOD occurs in the winter season mainly due to increasing rates of Black Carbon, organics, and sulphates [89]. According to this, Ramanathan et al. [14] reported that aerosols attenuate significantly the surface heating and evaporation and slow down the hydrological cycle, while Menon et al. [90] observed a large change in the precipitation distribution over south Asia attributed to the increased anthropogenic emissions. 

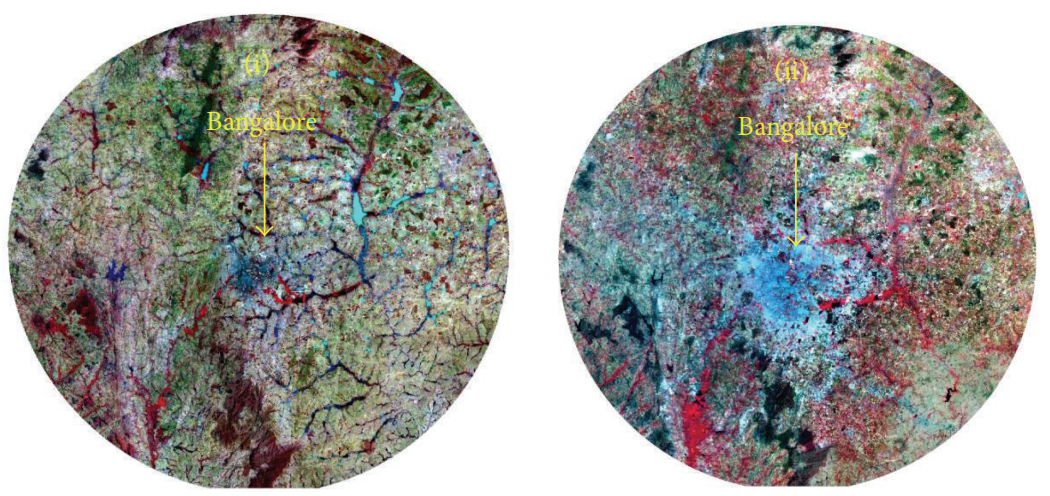

(a)
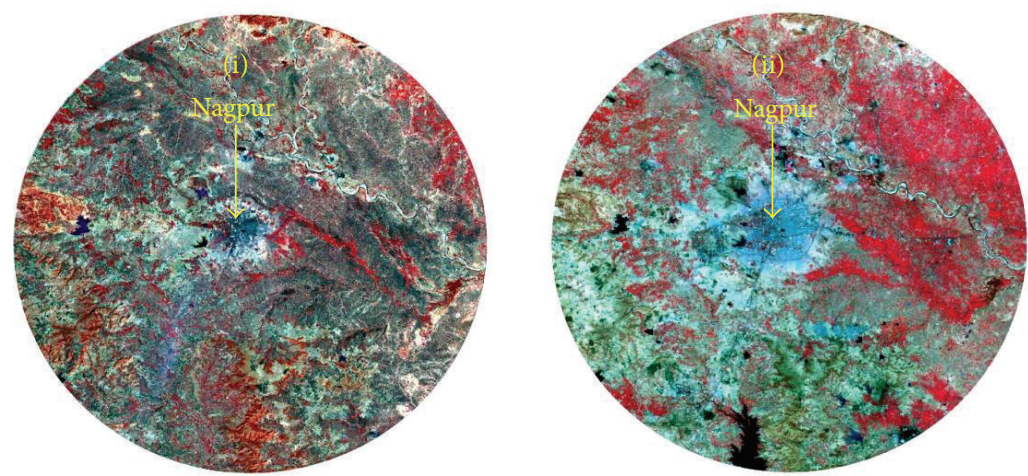

(b)
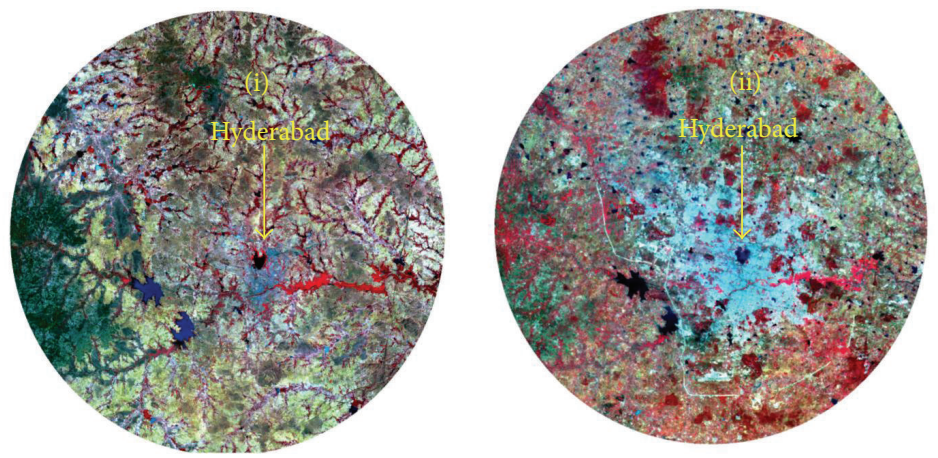

(c)

FIGURE 11: False color composite of (i) LANDSAT-MSS during 1972-73 and (ii) IRS-AWiFS during 2006-07 over Bangalore (a), Nagpur (b), and Hyderabad (c) cities.

More recently, Gautam et al. [91] found a strong influence of the increasing aerosol amount during premonsoon to the monsoon onset, duration, and intension. On the other hand, Lee et al. [49] noted a decrease in seasonal surface temperatures over Indian subcontinent as a result of massive irrigation that led to weakened Indian monsoon circulation.

However, several studies have shown a contrasting feature of precipitation that may increase or decrease due to anthropogenic aerosols, while the mechanisms remain mostly unclear involving microphysical, thermodynamic, and dynamic processes. Ayers [92] and Alpert et al. [93] disputed on the suppression of precipitation due to urban pollutions. Rosenfeld [94] noted suppression of rain due to forest fires in Indonesia via satellite observations, whereas Lin et al. [95] highlighted increasing rainfall trend associated with elevated aerosol layers during the biomass burning season in Amazonia. Jirak and Cotton [96] reported decrease in precipitation during the past half-century at downwind directions of Denver and Colorado Springs, contrary to other studies [97-99] that found increasing rainfall downwind of major urban areas possibly due to giant CCN from paper mills exhausts. On the other hand, Warner [100] by analyzing longterm ground measurements showed no evidence of subsequent changes in surface precipitation results that agree with 
those of Woodcock and Jones [101] over Hawaii. Therefore, there are critical difficulties for the quantitative examination of the rainfall trends over the urban environments in view of the trends in aerosol loading above them, since both parameters are significantly linked to other factors as well. This is also true in the current analysis, since no clear trend was found for the precipitation variation between upwind and downwind areas. The evidence of mostly decreasing trend and lesser precipitation amount in the downwind directions are not statistically significant at the majority of the cases. The low level moisture convergence, which is not considered in the current work, may play an important role in the cloud and precipitation formation [31, 68, 102]. In depth investigation into the microphysical properties of polluted clouds over the urban environments may better explain the precipitation trends and their association with aerosols and local pollutants. This is the concept of the recent, and still ongoing, cloud aerosol interactions and precipitation enhancement experiment (CAIPEEX) campaign over selected sites in India $[15,103]$.

The rapid population growth, LULC changes, and accelerated socioeconomic activities have modified the environment over India during the last decades [104]. Furthermore, LULC changes can significantly contribute to overall climate change and rainfall patterns [105]. Lamptey et al. [106] have investigated climatic sensitivity to agriculture and urban land cover over northeastern United States and found an increase of more than $1 \mathrm{~K}$ over the urban sites during summer and winter as a result of urbanization. The urban areas in India have experienced rapid human and industrial development during the last 50 years, which caused serious environmental degradation. Figures 11(a)-11(c) show the false color composite of Bangalore, Nagpur, and Hyderabad cities, respectively, during 1972-73 (Landsat-MSS) and 2006-07 (IRS-P6 AWiFS). Bangalore represents an uneven landscape with intermingling of hill and valleys with bare rocky outcrops and falls into high elevation zone. The change analysis between false color composites during 1972-73 and 2006-07 suggests large-scale expansion of Bangalore city; however, in addition to urban expansion, increase in vegetation conditions was also observed, which may be related to the increase in total precipitation (Figure 4) and number of rainy days (Figure 3), since the increase in leaf area index increases evapotranspiration and surface heating, thus favoring precipitation [107]. Nagpur city lies on the Deccan plateau of the Indian Peninsula and the surrounding region is undulating plateau rising northward to the Satpura range from 889 to 2142 feet high and is drained by several rivers. Nagpur also experienced expansion of urbanization along with increased vegetation activities over the study period. A large dam constructed towards south of the city is evident in 2006-07 image, which did not exist during 1972-73. The slight increase in rainfall (Figure 4) can be addressed to the increase in vegetation and enhanced evaporation from the man-made lake. Figure 11(c) shows a significant expansion in the urban area of Hyderabad during the last 3 decades, as well as important changes in the LULC outside the city, directly affecting the anthropogenic emissions and AOD [86]. Therefore, the changes in rainfall patterns, and mainly those between downwind and upwind

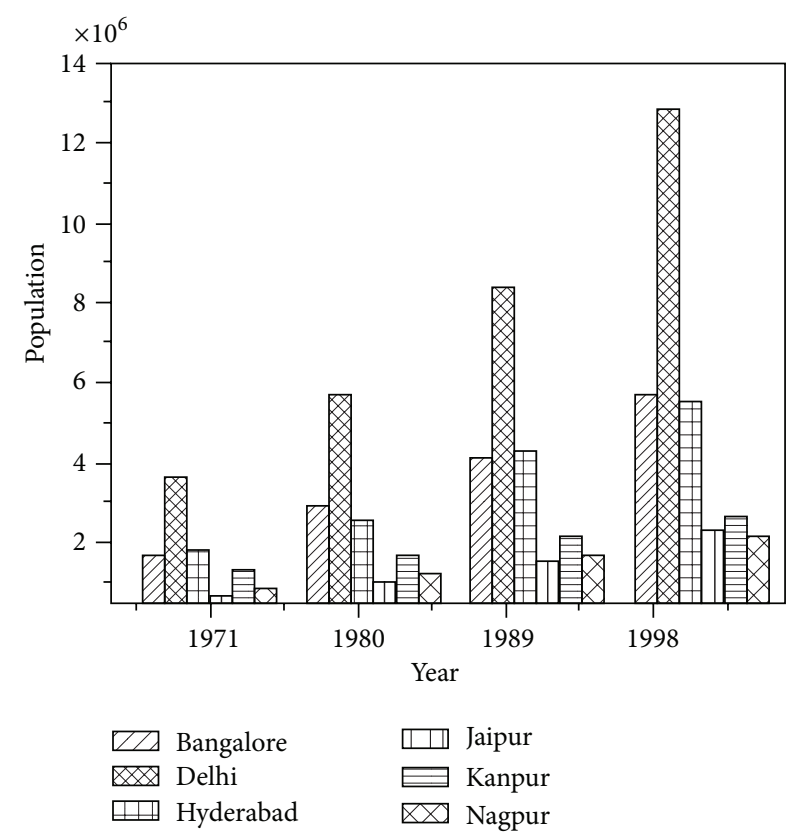

FIGURE 12: Population growth over the 6 Indian cities during 19711998.

directions around the urban areas, may be associated to the large LULC changes around the Indian cities and to increased number of automobiles, industries, and anthropogenic emissions. However, the linkage between urban areas expansion, anthropogenic emissions, and rainfall trends depends also on regional meteorology, topography, aerosol properties, and concentration of undisturbed cloud-active particles [108].

Figure 12 shows the population growth for the six Indian cities from 1971 to 1998. A pronounced increasing trend in population is found in all cities and, especially in Delhi, closely associated with the increasing aerosol and pollutant emissions [89]. However, Figure 12 covers only a part of the studied period and, therefore, the trend in population growth is expected to be higher if the 6 last decades are taken into account. Detailed analysis of the growing in population density and associated changes in precipitation has recently been reported by Kishtawal et al. [50]. The tremendous increase in population and associated emissions along with serious land degradation and LULC changes around the Indian cities enhance the urban heat island effect and modify the urban microclimate, which may also have effects on precipitation. Thus, the variation in precipitation amount and trends at upwind and downwind regions of the urban centers may partly be explained by the LULC changes, increase in population and emissions.

\section{Conclusions}

In the present study, we have analyzed the trends in monsoon rainfall and number of rainy days over six major Indian cities (Delhi, Hyderabad, Kanpur, Jaipur, Nagpur, and Bangalore) during the period 1951-2007. The study also provided an extensive literature overview concerning the precipitation 
trends and anthropogenic factors influencing it around the urban environments. The main results are summarized as follows.

(i) A decrease of $-21.3 \%,-5.9 \%,-14.2 \%$ and $-14.6 \%$, in seasonal monsoon rainfall was observed over Delhi, Hyderabad, Jaipur, and Kanpur, respectively, whereas Bangalore and Nagpur showed $65.8 \%$ and $13.4 \%$ increase during the period 1951-2007.

(ii) The total number of rainy days showed $7.4 \%$ and 22.9\% increase over Delhi and Bangalore cities; however, over Hyderabad, Jaipur, Kanpur, and Nagpur it showed $-10.4 \%,-10.5 \%,-7.1 \%$, and $-4.8 \%$ decrease in the monsoon season. These findings will be helpful to the public planners and agricultural scientists to work out irrigation and water management options as well as to prevent floods and droughts. However, in the vast majority of the cases the above-mentioned trends in rainfall amount and number of rainy days are not statistically significant at 95\% confidence level. Overall, the analysis did not reveal a clear trend in precipitation, which seems to be location-dependent.

(iii) The differences observed between the cities due to regional meteorology and topography and the statistical insignificance of the trends (in the vast majority of the cases) prevent us from a safe conclusion about the trend in monsoonal precipitation, although an evidence of a decreasing trend in the majority of the stations. In general, the decreasing trend seemed to be more pronounced in the downwind directions of each urban environment implying a possible anthropogenic forcing in precipitation, although such an influence cannot be quantified due to lack of statistical significance. The long-term rainfall data revealed that the suppression of precipitation exhibits a slight increasing trend during the last decades further motivated from the continuously increasing emission rates. The urban areas produce large amounts of pollutants, which increase the number of cloud condensation nuclei in the atmosphere and decrease the mean droplet radius. This creates a lack of coalescence and inhibits precipitation formation, especially in the downwind to the cities directions. On the other hand, urban pollution may increase heavy rainfall as some studies showed. Aerosol-cloud-precipitation interactions are complicated phenomena involving several microphysical, dynamic, and thermodynamic processes. Therefore, a more detailed analysis and evaluation of the results necessitate measured gauge precipitation in upwind and downwind directions of the cities as well as advanced model simulations.

\section{Acknowledgments}

The authors thank the Director of the National Remote Sensing Center (NRSC), Hyderabad and the Dy. Director of the RS\&GIS-AA, NRSC for the necessary help at various stages and ISRO-GBP for funding support. The authors gratefully acknowledge Indian Meteorological Department (IMD) for providing gridded rainfall dataset over Indian region. The authors would like to thank the NCEP/NCAR science data support team for processing the meteorological data and the Landsat and IRS missions. The authors are thankful to their colleague late Dr. K. V. Badarinath for his help and suggestions in completing this work. Comments/ suggestions made by three anonymous reviewers are thankfully acknowledged that have helped us to improve the earlier version of the paper.

\section{References}

[1] L. S. Kuchment, "The hydrological cycle and human impact on it," in Water Resources ManagementEncyclopedia of Life Support Systems (EOLSS), Developed under the Auspices of the UNESCO, A. Y. Hoekstra and H. H. G. Savenije, Eds., Eolss Publishers, Oxford, UK.

[2] D. Rosenfeld, U. Lohmann, G. B. Raga et al., "Flood or drought: how do aerosols affect precipitation?" Science, vol. 321, no. 5894, pp. 1309-1313, 2008.

[3] K. R. Kumar, G. B. Pant, B. Parthasarathy, and N. A. Sontakke, "Spatial and subseasonal patterns of the long-term trends of Indian summer monsoon rainfall," International Journal of Climatology, vol. 12, no. 3, pp. 257-268, 1992.

[4] A. Basistha, D. S. Arya, and N. K. Goel, "Analysis of historical changes in rainfall in the Indian Himalayas," International Journal of Climatology, vol. 29, no. 4, pp. 555-572, 2009.

[5] D. Duhan and A. Pandey, "Statistical analysis of long term spatial and temporal trends of precipitation during 1901-2002 at Madhya Pradesh, India," Atmospheric Research, vol. 122, pp. 136-149, 2013.

[6] K. C. Sinha Ray and A. K. Srivastava, "Is there any change in extreme events like heavy rainfall?" Current Science, vol. 79, no. 2, pp. 155-158, 2000.

[7] B. N. Goswami, V. Venugopal, D. Sangupta, M. S. Madhusoodanan, and P. K. Xavier, "Increasing trend of extreme rain events over India in a warming environment," Science, vol. 314, no. 5804, pp. 1442-1445, 2006.

[8] N. Malik, B. Bookhagen, N. Marwan, and J. Kurths, "Analysis of spatial and temporal extreme monsoonal rainfall over South Asia using complex networks," Climate Dynamics, pp. 1-17, 2011.

[9] P. Guhathakurtha, P. Menon, A. B. Mazumdar, and O. P. Sreejith, "Changes in extreme rainfall events and flood risk in India during last century," Research Report 14, India Met Department, National Climate Centre (NCC), Pune, 2010.

[10] S. K. Dash, J. R. Kumar, and M. S. Shekhar, "On the decreasing frequency of monsoon depressions over the Indian region," Current Science, vol. 86, no. 10, pp. 1404-1411, 2004.

[11] M. Lal, "Climatic change-implications for India's water resources," Journal of Indian Water Resources Society, vol. 21, pp. 101-119, 2001.

[12] S. M. Bawiskar, "Weakening of lower tropospheric temperature gradient between Indian landmass and neighbouring oceans and its impact on Indian monsoon," Journal of Earth System Science, vol. 118, no. 4, pp. 273-280, 2009.

[13] D. Rosenfeld, "Suppression of rain and snow by urban and industrial air pollution," Science, vol. 287 , no. 5459 , pp. $1793-$ 1796, 2000. 
[14] V. Ramanathan, P. J. Crutzen, J. T. Kiehl, and D. Rosenfeld, "Atmosphere: aerosols, climate, and the hydrological cycle," Science, vol. 294, no. 5549, pp. 2119-2124, 2001.

[15] S. Dipu, T. V. Prabha, G. Pandithurai et al., "Impact of elevated aerosol layer on the cloud microphysical properties prior to monsoon onset," Atmospheric Environment, vol. 70, pp. 454467, 2013.

[16] V. Ramaswamy, "Radiative forcing of climate change," in Climate Change 2001: The Scientific Basis, Contribution of Working Group I to the Third Assessment Report of the Intergovernmental Panel on Climate Change, J. T. Houghton, Y. Ding, D. J. Griggs, M. Noguer, P. J. van der Linden, and X. Dai, Eds., chapter 6, Cambridge University Press, Cambridge, UK, 2001.

[17] U. Lohmann and J. Feichter, "Global indirect aerosol effects: a review," Atmospheric Chemistry and Physics, vol. 5, no. 3, pp. 715-737, 2005.

[18] M. O. Andreae, D. Rosenfeld, P. Artaxo et al., "Smoking Rain Clouds over the Amazon," Science, vol. 303, no. 5662, pp. 13371342, 2004.

[19] A. Givati and D. Rosenfeld, "Quantifying precipitation suppression due to air pollution," Journal of Applied Meteorology, vol. 43, pp. 1038-1056, 2004.

[20] D. Rosenfeld, J. Dai, X. Yu et al., "Inverse relations between amounts of air pollution and orographic precipitation," Science, vol. 315, no. 5817, pp. 1396-1398, 2007.

[21] R. D. Borys, D. H. Lowenthal, S. A. Cohn, and W. O. J. Brown, "Mountaintop and radar measurements of anthropogenic aerosol effects on snow growth and snowfall rate," Geophysical Research Letters, vol. 30, no. 10, pp. 45-1, 2003.

[22] R. D. Borys, D. H. Lowenthal, and D. L. Mitchell, "The relationships among cloud microphysics, chemistry, and precipitation rate in cold mountain clouds," Atmospheric Environment, vol. 34, no. 16, pp. 2593-2602, 2000.

[23] D. Rosenfeld, W. L. Woodley, D. Axisa, E. Freud, J. G. Hudson, and A. Givati, "Aircraft measurements of the impacts of pollution aerosols on clouds and precipitation over the Sierra Nevada," Journal of Geophysical Research D, vol. 113, no. 15, Article ID D15203, 2008.

[24] D. P. Kaiser and Y. Qian, "Decreasing trends in sunshine duration over China for 1954-1998: indication of increased haze pollution?" Geophysical Research Letters, vol. 29, no. 21, pp. 38-1, 2002.

[25] Q. Xu, "Abrupt change of the mid-summer climate in central east China by the influence of atmospheric pollution," Atmospheric Environment, vol. 35, no. 30, pp. 5029-5040, 2001.

[26] Y. Qian, W. Wang, L. R. Leung, and D. P. Kaiser, "Variability of solar radiation under cloud-free skies in China: the role of aerosols," Geophysical Research Letters, vol. 34, no. 12, Article ID L12804, 2007.

[27] G. Habib, C. Venkataraman, I. Chiapello, S. Ramachandran, O. Boucher, and M. Shekar Reddy, "Seasonal and interannual variability in absorbing aerosols over India derived from TOMS: relationship to regional meteorology and emissions," Atmospheric Environment, vol. 40, no. 11, pp. 1909-1921, 2006.

[28] Z. Levin and W. Cotton, "Aerosol pollution impact on precipitation: a scientific review," Report from the WMO/IUGG International Aerosol Precipitation Science Assessment Group (IAPSAG) (World Meteorological Organization, Geneva, Switzerland, 2007), 2007.

[29] A. K. Prasad, S. Sarkar, R. P. Singh, and M. Kafatos, "Interannual variability of vegetation cover and rainfall over india," Advances in Space Research, vol. 39, no. 1, pp. 79-87, 2007.
[30] S. Sarkar, L. Chiu, M. Kafatos, and R. Singh, "Sensitivity of rainfall on land cover change over South East Asia: some observational results," Advances in Space Research, vol. 39, no. 1, pp. 73-78, 2007.

[31] M. G. Manoj, P. C. S. Devara, P. D. Safai, and B. N. Goswami, "Absorbing aerosols facilitate transition of Indian monsoon breaks to active spells," Climate Dynamics, vol. 37, no. 11-12, pp. 2181-2198, 2011.

[32] A. Teller and Z. Levin, "The effects of aerosols on precipitation and dimensions of subtropical clouds: a sensitivity study using a numerical cloud model," Atmospheric Chemistry and Physics, vol. 6, no. 1, pp. 67-80, 2006.

[33] W.-K. Tao, X. Li, A. Khain, T. Matsui, S. Lang, and J. Simpson, "Role of atmospheric aerosol concentration on deep convective precipitation: cloud-resolving model simulations," Journal of Geophysical Research D, vol. 112, no. 24, Article ID D24S18, 2007.

[34] W.-K. Tao, J.-P. Chen, Z. Li, C. Wang, and C. Zhang, "Impact of aerosols on convective clouds and precipitation," Reviews of Geophysics, vol. 50, Article ID RG2001, 2012.

[35] G. Li, Y. Wang, K.-H. Lee, Y. Diao, and R. Zhang, "Increased winter precipitation over the North Pacific from 1984-1994 to 1995-2005 inferred from the global precipitation climatology project," Geophysical Research Letters, vol. 35, no. 13, Article ID L13821, 2008.

[36] D. S. Niyogi, S. Raman, and K. Alapaty, "Uncertainty in the specification of surface characteristics, part II: hierarchy of interaction-explicit statistical analysis," Boundary-Layer Meteorology, vol. 91, no. 3, pp. 341-366, 1999.

[37] R. A. Pielke Sr., "Influence of the spatial distribution of vegetation and soils on the prediction of cumulus convective rainfall," Reviews of Geophysics, vol. 39, no. 2, pp. 151-177, 2001.

[38] S. B. Roy and R. Avissar, "Impact of land use/land cover change on regional hydrometeorology in Amazonia," Journal of Geophysical Research D, vol. 107, no. 20, pp. 67-68, 2002.

[39] D. K. Ray, U. S. Nair, R. O. Lawton, R. M. Welch, and R. A. Pielke Sr., "Impact of land use on Costa Rican tropical montane cloud forests: sensitivity of orographic cloud formation to deforestation in the plains," Journal of Geophysical Research D, vol. 111, no. 2, Article ID D02108, 2006.

[40] C. H. Marshall, R. A. Pielke Sr., L. T. Steyaert, and D. A. Willard, "The impact of anthropogenic land-cover change on the Florida Peninsula Sea Breezes and warm season sensible weather," Monthly Weather Review, vol. 132, no. 1, pp. 28-52, 2004.

[41] E. M. Douglas, A. Beltrán-Przekurat, D. Niyogi, R. A. Pielke Sr., and C. J. Vörösmarty, "The impact of agricultural intensification and irrigation on land-atmosphere interactions and Indian monsoon precipitation-a mesoscale modeling perspective," Global and Planetary Change, vol. 67, no. 1-2, pp. 117-128, 2009.

[42] V. Mishra, K. A. Cherkauer, D. Niyogi et al., "A regional scale assessment of land use/land cover and climatic changes on water and energy cycle in the upper Midwest United States," International Journal of Climatology, vol. 30 , no. 13, pp. 20252044, 2010

[43] J. M. Shepherd, H. Pierce, and A. J. Negri, "Rainfall modification by major urban areas: observations from spaceborne rain radar on the TRMM satellite," Journal of Applied Meteorology, vol. 41, no. 7, pp. 689-701, 2002.

[44] D. Niyogi, T. Holt, S. Zhong, P. C. Pyle, and J. Basara, "Urban and land surface effects on the 30 July 2003 mesoscale convective system event observed in the southern Great Plains," Journal of Geophysical Research D, vol. 111, no. 19, Article ID D19107, 2006. 
[45] T. L. Mote, M. C. Lacke, and J. M. Shepherd, "Radar signatures of the urban effect on precipitation distribution: a case study for Atlanta, Georgia," Geophysical Research Letters, vol. 34, no. 20, Article ID L20710, 2007.

[46] T. R. Oke, “The urban energy balance," Progress in Physical Geography, vol. 12, no. 4, pp. 471-508, 1988.

[47] X. Zhang, F. W. Zwiers, G. C. Hegerl et al., "Detection of human influence on twentieth-century precipitation trends," Nature, vol. 448, no. 7152, pp. 461-465, 2007.

[48] R. K. Kaufmann, K. C. Seto, A. Schneider, Z. Liu, L. Zhou, and W. Wang, "Climate response to rapid urban growth: evidence of a human-induced precipitation deficit," Journal of Climate, vol. 20, no. 10, pp. 2299-2306, 2007.

[49] E. Lee, T. N. Chase, B. Rajagopalan, R. G. Barry, T. W. Biggs, and P. J. Lawrence, "Effects of irrigation and vegetation activity on early Indian summer monsoon variability," International Journal of Climatology, vol. 29, no. 4, pp. 573-581, 2009.

[50] C. M. Kishtawal, D. Niyogi, M. Tewari, R. A. Pielke, and J. M. Shepherd, "Urbanization signature in the observed heavy rainfall climatology over India," International Journal of Climatology, vol. 30, no. 13, pp. 1908-1916, 2010.

[51] S. Ramachandran and R. Cherian, "Regional and seasonal variations in aerosol optical characteristics and their frequency distributions over India during 2001-2005," Journal of Geophysical Research D, vol. 113, no. 8, Article ID D08207, 2008.

[52] S. Singh, K. Soni, T. Bano, R. S. Tanwar, S. Nath, and B. C. Arya, "Clear-sky direct aerosol radiative forcing variations over megacity Delhi," Annales Geophysicae, vol. 28, no. 5, pp. 1157-1166, 2010.

[53] S. Singh, S. Nath, R. Kohli, and R. Singh, "Aerosols over Delhi during pre-monsoon months: characteristics and effects on surface radiation forcing," Geophysical Research Letters, vol. 32, no. 13, Article ID L13808, pp. 1-4, 2005.

[54] K. M. Latha, K. V. S. Badarinath, and K. K. Moorthy, "Impact of diesel vehicular emissions on ambient black carbon concentration at an urban location in India," Current Science, vol. 86, no. 3, pp. 451-453, 2004.

[55] S. K. Kharol and K. V. S. Badarinath, "Impact of biomass burning on aerosol properties over tropical urban region of Hyderabad, India," Geophysical Research Letters, vol. 33, no. 20, Article ID L20801, 2006.

[56] K. V. S. Badarinath, S. K. Kharol, D. G. Kaskaoutis, and H. D. Kambezidis, "Case study of a dust storm over Hyderabad area, India: its impact on solar radiation using satellite data and ground measurements," Science of the Total Environment, vol. 384, no. 1-3, pp. 316-332, 2007.

[57] K. V. S. Badarinath, S. Kumar Kharol, and A. Rani Sharma, "Long-range transport of aerosols from agriculture crop residue burning in Indo-Gangetic Plains-a study using LIDAR, ground measurements and satellite data," Journal of Atmospheric and Solar-Terrestrial Physics, vol. 71, no. 1, pp. 112-120, 2009.

[58] V. Sreekanth, "Satellite derived aerosol optical depth climatology over Bangalore, India," Advances in Space Research, vol. 51, no. 12, pp. 2297-2308, 2013.

[59] R. P. Singh, S. Dey, S. N. Tripathi, V. Tare, and B. Holben, "Variability of aerosol parameters over Kanpur, northern India," Journal of Geophysical Research D, vol. 109, no. 23, Article ID D23206, pp. 1-14, 2004.

[60] A. K. Srivastava, S. N. Tripathi, S. Dey, V. P. Kanawade, and S. Tiwari, "Inferring aerosol types over the Indo-Gangetic Basin from ground based sunphotometer measurements," Atmospheric Research, vol. 109-110, pp. 64-75, 2012.

[61] R. Gautam, N. C. Hsu, S. C. Tsay et al., "Accumulation of aerosols over the Indo-Gangetic plains and southern slopes of the Himalayas: distribution, properties and radiative effects during the 2009 pre-monsoon season," Atmospheric Chemistry and Physics, vol. 11, no. 24, pp. 12841-12863, 2011.

[62] J. Singh, M. Kumar, and B. K. Bhattacharya, "Global radiation, transmissivity and bright sunshine hour trend over Nagpur in pre-monsoon and monsoon seasons," Atmospheric and Climate Sciences, vol. 2, pp. 206-209, 2012.

[63] M. Rajeevan, J. Bhate, J. D. Kale, and B. Lal, "High resolution daily gridded rainfall data for the Indian region: analysis of break and active monsoon spells," Current Science, vol. 91, no. 3, pp. 296-306, 2006.

[64] D. Shepard, "A two-dimensional interpolation function for irregularly spaced data," in Proceedings of the 23rd ACM National Conference, pp. 517-523, 1968.

[65] D. G. Kaskaoutis, R. Gautam, R. P. Singh et al., "Influence of anomalous dry conditions on aerosols over India: transport, distribution and properties," Journal of Geophysical Research, vol. 117, Article ID D09106, 2012.

[66] A. Yatagai, K. Kamiguchi, O. Arakawa, A. Hamada, N. Yasutomi, and A. Kitoh, "Constructing a long-term daily gridded precipitation dataset for Asia based on a dense network of rain gauges," Bulletin of the American Meteorological Society, vol. 93, pp. 1401-1415, 2012.

[67] R. Krishnan, T. P. Sabin, D. C. Ayantika et al., "Will the South Asian monsoon overturning circulation stabilize any further?" Climate Dynamics, vol. 40, pp. 187-211, 2013.

[68] P. K. Patra, S. K. Behera, J. R. Herman, S. Maksyutov, H. Akimoto, and T. Yamagata, "The Indian summer monsoon rainfall: interplay of coupled dynamics, radiation and cloud microphysics," Atmospheric Chemistry and Physics, vol. 5, no. 8, pp. 2181-2188, 2005.

[69] U. S. De and G. S. Prakas Rao, "Urban climatic trends, 2004," Journal of Indian Geophysical Union, vol. 8, no. 3, pp. 199-203, 2004.

[70] M. R. Allen and W. J. Ingram, "Constraints on future changes in climate and the hydrologic cycle," Nature, vol. 419, no. 6903, pp. 224-232, 2002.

[71] K. E. Trenberth, A. Dai, R. M. Rasmussen, and D. B. Parsons, "The changing character of precipitation," Bulletin of the American Meteorological Society, vol. 84, no. 9, pp. 1205-1161, 2003.

[72] K. V. S. Badarinath, A. R. Sharma, D. G. Kaskaoutis, S. K. Kharol, and H. D. Kambezidis, "Solar dimming over the tropical urban region of Hyderabad, India: effect of increased cloudiness and increased anthropogenic aerosols," Journal of Geophysical Research D, vol. 115, no. 21, Article ID D21208, 2010.

[73] C. Bhuiyan, R. P. Singh, and W. A. Flügel, "Modelling of ground water recharge-potential in the hard-rock Aravalli terrain, India: a GIS approach," Environmental Earth Sciences, vol. 59, no. 4, pp. 929-938, 2009.

[74] P. Guhathakurta and M. Rajeevan, "Trends in the rainfall pattern over India," International Journal of Climatology, vol. 28, no. 11, pp. 1453-1469, 2008.

[75] R. L. Bhawar and P. C. S. Devara, "Study of successive contrasting monsoons (2001-2002) in terms of aerosol variability over a tropical statio Pune, India," Atmospheric Chemistry and Physics, vol. 10, no. 1, pp. 29-37, 2010. 
[76] R. Gautam, N. C. Hsu, K.-M. Lau, and M. Kafatos, "Aerosol and rainfall variability over the Indian monsoon region: distributions, trends and coupling," Annales Geophysicae, vol. 27, no. 9, pp. 3691-3703, 2009.

[77] O. B. Toon, "How pollution suppresses rain," Science, vol. 287, no. 5459, pp. 1763-1765, 2000.

[78] A. Givati and D. Rosenfeld, "Separation between cloud-seeding and air-pollution effects," Journal of Applied Meteorology, vol. 44, no. 9, pp. 1298-1314, 2005.

[79] S. T. Massie, O. Torres, and S. J. Smith, “Total Ozone Mapping Spectrometer (TOMS) observations of increases in Asian aerosol in winter from 1979 to 2000," Journal of Geophysical Research D, vol. 109, no. 18, pp. D18211-14, 2004.

[80] K. K. Moorthy, S. S. Babu, M. R. Manoj, and S. K. Satheesh, "Buildup of aerosols over the Indian Region," Geophysical Research Letters, vol. 40, no. 5, pp. 1011-1014, 2013.

[81] P. Kishcha, B. Starobinets, O. Kalashnikova, and P. Alpert, "Aerosol optical thickness trends and population growth in the Indian subcontinent," International Journal of Remote Sensing, vol. 32, no. 24, pp. 9137-9149, 2011.

[82] A. Ohmura, "Observed decadal variations in surface solar radiation and their causes," Journal of Geophysical Research, vol. 114, Article ID D00D05, 2009.

[83] V. Ramanathan, C. Chung, D. Kim et al., "Atmospheric brown clouds: impacts on South Asian climate and hydrological cycle," Proceedings of the National Academy of Sciences of the United States of America, vol. 102, no. 15, pp. 5326-5333, 2005.

[84] N. K. Lodhi, S. N. Beegum, S. Singh, and K. Kumar, "Aerosol climatology at Delhi in the Western Indo Gangetic Plain: microphysics, long-term trends and source strengths," Journal of Geophysical Research, vol. 118, pp. 1-15, 2013.

[85] D. G. Kaskaoutis, R. P. Singh, R. Gautam, M. Sharma, P. G. Kosmopoulos, and S. N. Tripathi, "Variability and trends of aerosol properties over Kanpur, northern India using AERONET data (2001-10)," Environmental Research Letters, vol. 7, no. 2, Article ID 024003, 2012.

[86] S. K. Kharol, K. V. S. Badarinath, A. R. Sharma, D. G. Kaskaoutis, and H. D. Kambezidis, "Multiyear analysis of Terra/Aqua MODIS aerosol optical depth and ground observations over tropical urban region of Hyderabad, India," Atmospheric Environment, vol. 45, no. 8, pp. 1532-1542, 2011.

[87] K. K. Moorthy, S. S. Babu, S. K. Satheesh et al., "Climate implications of anthropogenic aerosols and trace gases: Indian scenario," in WCC-3 Climate Sense, G. R. Asrar, Ed., pp. 157-160, World Meteorological Organization, Tudor Rose, UK, 2009.

[88] K. K. Dani, P. Ernest Raj, P. C. S. Devara et al., "Long-term trends and variability in measured multi-spectral aerosol optical depth over a tropical urban station in India," International Journal of Climatology, vol. 32, no. 1, pp. 153-160, 2012.

[89] Z. Lu, Q. Zhang, and D. G. Streets, "Sulfur dioxide and primary carbonaceous aerosol emissions in China and India, 19962010," Atmospheric Chemistry and Physics, vol. 11, no. 18, pp. 9839-9864, 2011

[90] S. Menon, J. Hansen, L. Nazarenko, and Y. Luo, "Climate effects of black carbon aerosols in China and India," Science, vol. 297, no. 5590, pp. 2250-2253, 2002.

[91] R. Gautam, N. C. Hsu, K.-M. Lau, S.-C. Tsay, and M. Kafatos, "Enhanced pre-monsoon warming over the HimalayanGangetic region from 1979 to 2007," Geophysical Research Letters, vol. 36, no. 7, Article ID L07704, 2009.
[92] G. P. Ayers, "Air pollution and climate change: has air pollution suppressed rainfall over Australia?" Clean Air and Environmental Quality, vol. 39, pp. 51-57, 2005.

[93] P. Alpert, N. Halfon, and Z. Levin, "Does air pollution really suppress precipitation in Israel?" Journal of Applied Meteorology and Climatology, vol. 47, no. 4, pp. 933-943, 2008.

[94] D. Rosenfeld, "TRMM observed first direct evidence of smoke from forest fires inhibiting rainfall," Geophysical Research Letters, vol. 26, no. 20, pp. 3105-3108, 1999.

[95] J. C. Lin, T. Matsui, S. Pielke, and C. Kummerow, "Effects of biomass-burning-derived aerosols on precipitations and clouds in the Amazon Basin: a satellite-based empirical study," Journal of Geophysical Research D, vol. 111, no. 19, Article ID D19204, 2006.

[96] I. L. Jirak and W. R. Cotton, "Effect of air pollution on precipitation along the front range of the rocky mountains," Journal of Applied Meteorology and Climatology, vol. 45, no. 1, pp. 236-245, 2006.

[97] E. E. Hindman II, P. M. Tag, B. A. Silverman, and P. V. Hobbs, "Cloud condensation nuclei from a paper mill. 2. Calculated effects on rainfall," Journal of Applied Meteorology, vol. 16, no. 7, pp. 753-755, 1977.

[98] R. R. Braham Jr., "Summary of urban effects on clouds and rain," Meteorological Monographs, vol. 18, no. 40, pp. 141-152, 1981.

[99] G. K. Mather, "Coalescence enhancement in large multicell storms caused by the emissions from a kraft paper mill," Journal of Applied Meteorology, vol. 30, no. 8, pp. 1134-1146, 1991.

[100] J. Warner, "Smoke from sugar-cane fires and rainfall," in Proceedings of International Conference on Weather Modification, pp. 191-192, American Meteorological Society, Canberra, Canada, 1971.

[101] A. H. Woodcock and R. H. Jones, "Rainfall trends in Hawaii," Journal of Applied Meteorology, vol. 9, pp. 690-696, 1970.

[102] A. Hazra, V. Mandal, and J. P. Chen, "Study of cloud microphysical properties over India during CAIPEEX using a mesoscale model with new cloud microphysical scheme-part I," Journal of Atmospheric and Solar-Terrestrial Physics, vol. 93, pp. 29-44, 2013.

[103] K. Chakravarty, P. Mukhopadhyay, and S. Taraphdar, "Cloud microphysical properties as revealed by the CAIPEEX and satellite observations and evaluation of a cloud system resolving model simulation of contrasting large scale environments," Journal of Atmospheric and Solar-Terrestrial Physics, vol. 73, no. 13, pp. 1790-1797, 2011.

[104] R. Gautam, N. C. Hsu, and K.-M. Lau, "Premonsoon aerosol characterization and radiative effects over the Indo-Gangetic plains: implications for regional climate warming," Journal of Geophysical Research D, vol. 115, no. 17, Article ID D17208, 2010.

[105] S. J. Burian and J. M. Shepherd, "Effect of urbanization on the diurnal rainfall pattern in Houston," Hydrological Processes, vol. 19, no. 5, pp. 1089-1103, 2005.

[106] B. L. Lamptey, E. J. Barron, and D. Pollard, "Impacts of agriculture and urbanization on the climate of the Northeastern United States," Global and Planetary Change, vol. 49, no. 3-4, pp. 203-221, 2005.

[107] Y. Kim and G. Wang, "Impact of vegetation feedback on the response of precipitation to antecedent soil moisture anomalies over North America," Journal of Hydrometeorology, vol. 8, no. 3, pp. 534-550, 2007.

[108] E. K. Bigg, "Trends in rainfall associated with sources of air pollution," Environmental Chemistry, vol. 5, no. 3, pp. 184-193, 2008. 

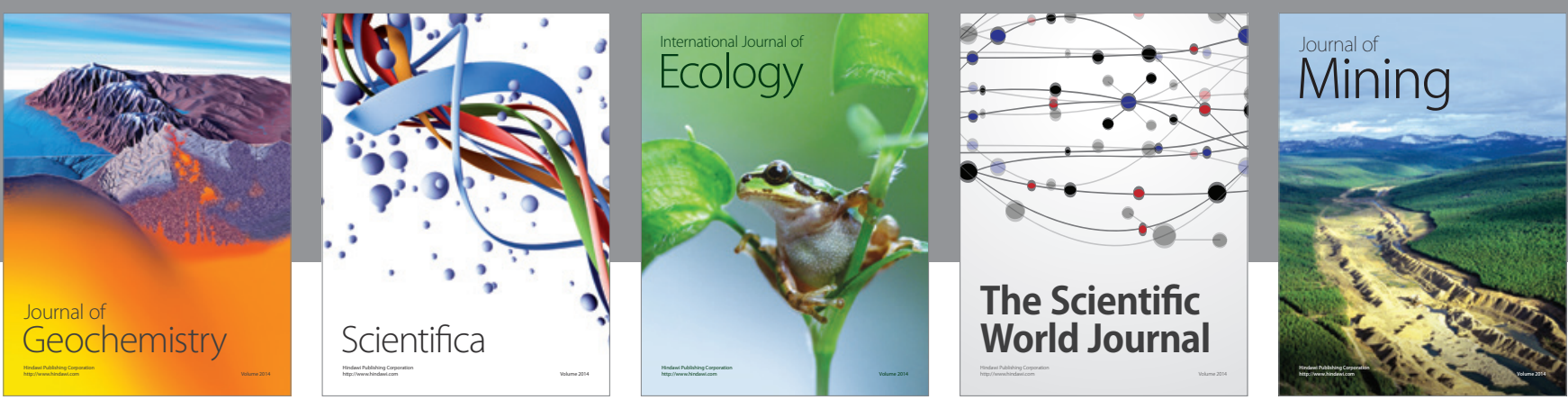

The Scientific World Journal
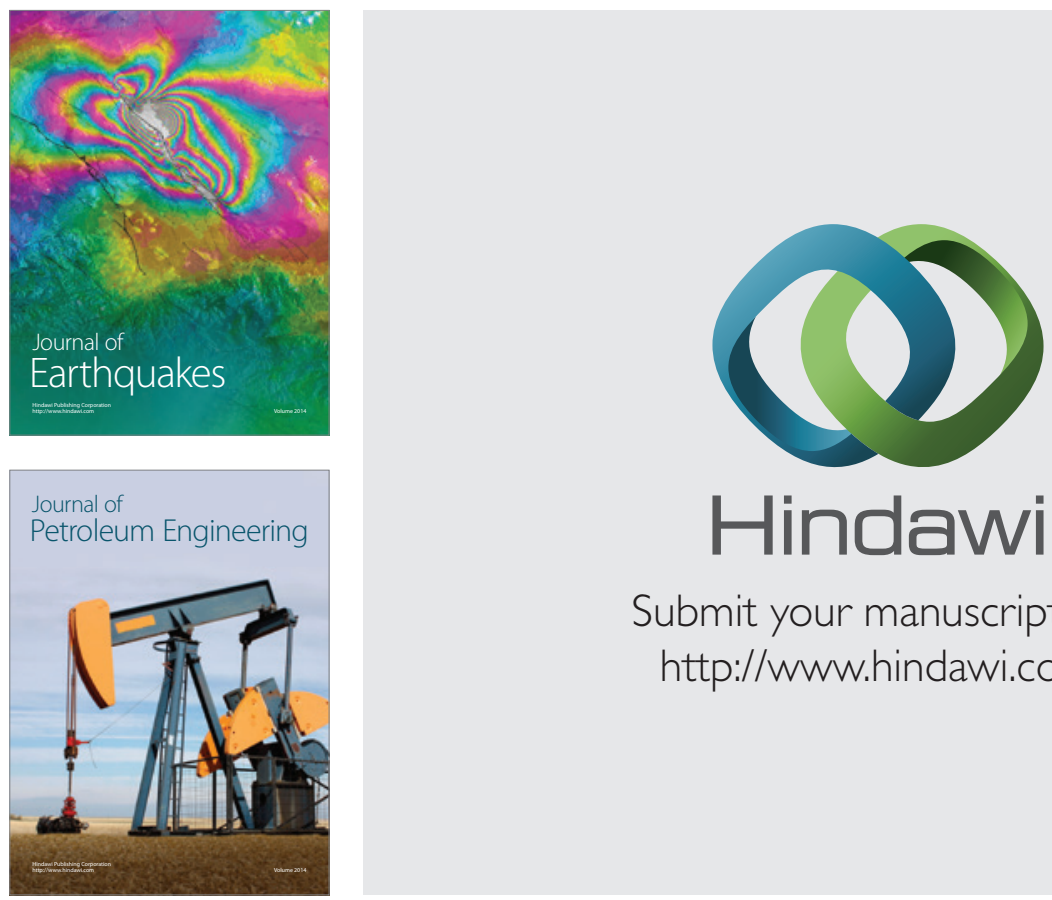

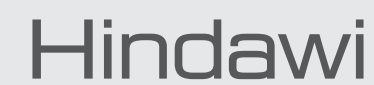

Submit your manuscripts at

http://www.hindawi.com
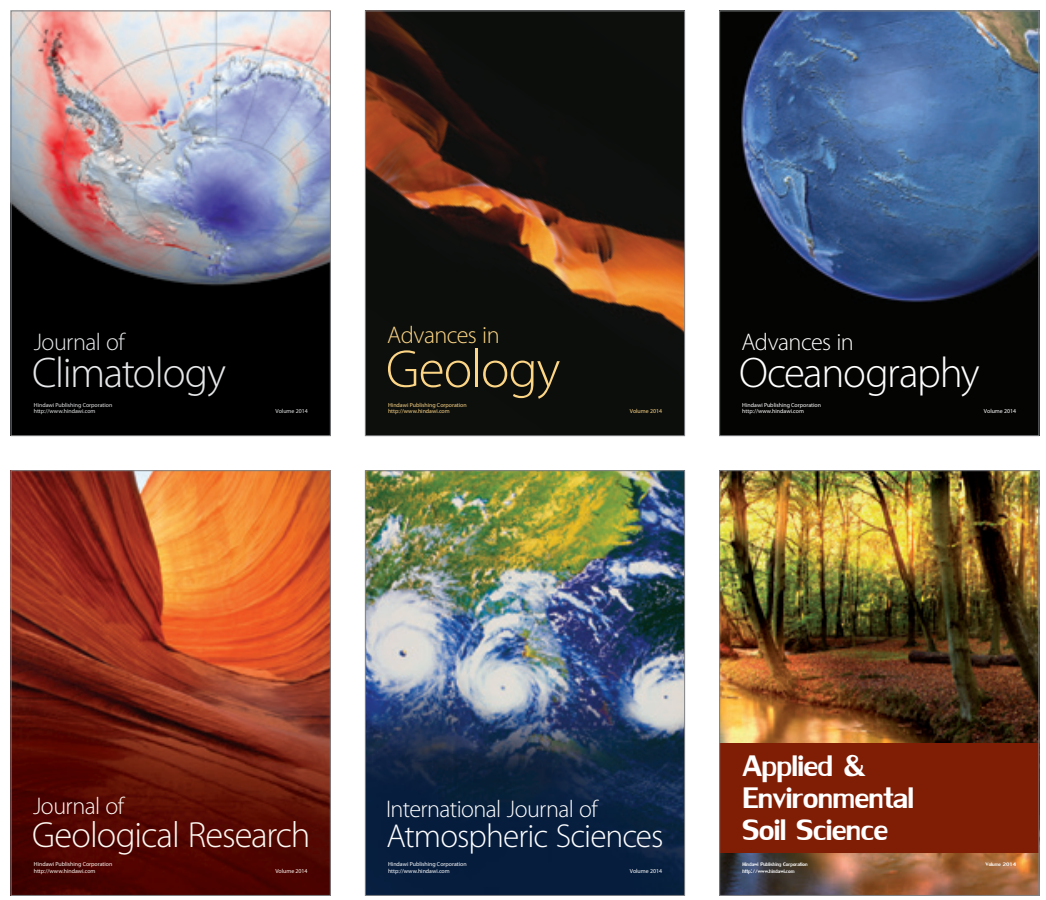
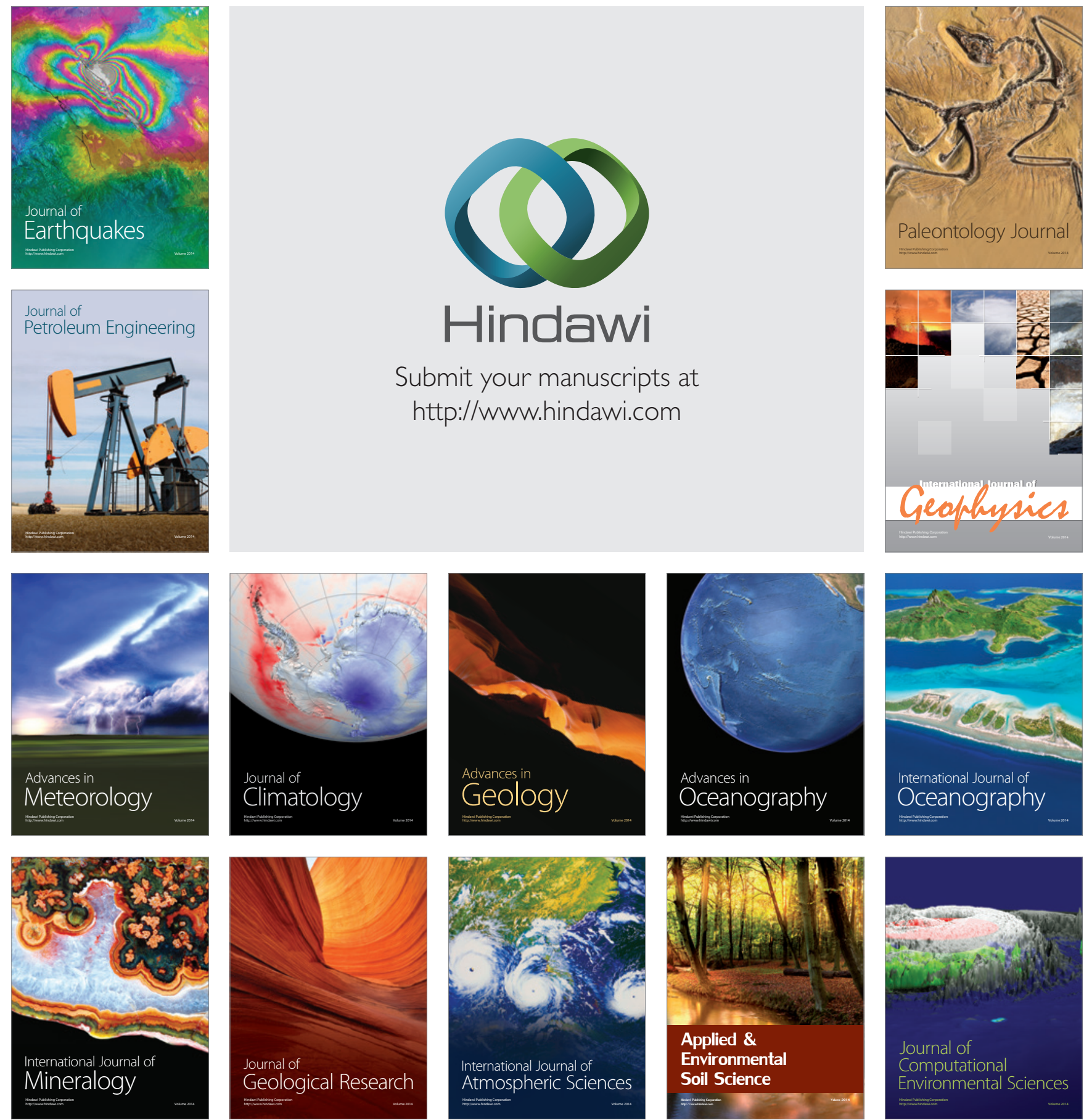